\title{
Demokratik Yönetimlerde Profan Meşruluğun Olabilirliği
}

Metin UÇAR

\section{The Possibility of a Profane Legitimacy in} Democratic Governments

Citation/@: Uçar, Metin, (2017). The Possibility of a Profane Legitimacy in Democratic Governments, Milel ve Nihal, 14 (1), 96-134.

Abstract: This paper does not concern theology. Rather it focuses on legitimacy, one of the most important subjects of political science. The possibility of a profane legitimacy is primarily discussed; the thesis is that a complete profane legitimacy is not possible and that profanity must always refer to sanctification. This sanctification does not follow the traditional religious definition. It covers everything in the context of divine or secular glorification. The principles that most secular ideologists aim to die for are the best examples of these sanctifications. In particular, aggrandization of each identity such as the beliefs that the nations derive from legend and the rituals that transform these beliefs explain this kind of sanctities. This work is aimed at revealing secular legitimacy which is a claim to profanity but can not be exclusive of the sanctuary.

Key Words: Democracy, governance, profan, legitimacy.

Doç. Dr., Hitit Üniversitesi, İktisadi ve İdari Bilimler Fakültesi, Siyaset ve Sosyal Bilimler Anabilim Dalı [metucar@yahoo.com] 
Atıf/@: Uçar, Metin, (2017). Demokratik Yönetimlerde Profan Meşruluğun Olabilirliği, Milel ve Nihal, 14 (1), 96-134.

Öz: Bu çalışma teoloji ile ilgili değildir. Siyaset biliminin en önemli konularından biri olan meşruluğa odaklanmakta ve profan bir meşruluğun olabilirliğini tartışmaktadır. Çalışmanın temel tezi, profan bir meşruluğun tam olarak mümkün olmadığı ve her halükarda profanın kutsala başvurmak zorunda kaldığıdır. Bu kutsallık dinsel olanın özcü tanımındaki bir kutsallık değildir. İlahi olabileceği gibi dünyevi yüceltmeleri kapsayan, insan akIının ötesine geçmeyi hedefleyen, hümanist olmayan ve bu bağlamda insanı aşan her şeyi kapsamaktadır. En seküler ideolojilerin uğrunda ölmeyi hedefledikleri ilkeler, bu kutsala verilebilecek en iyi örneklerdir. Özellikle ulusların efsanelerden türettikleri inançları ve bu inançları dönüştürdükleri ritüelleri gibi her bir kimliğin yücelttiği dışavurumları bu tarz bir kutsalı anlatır. Bu çalışma tam da buradan hareketle profanlık iddiaları olan ama kutsalın dışına çıkamayan laik/seküler meşruluk anlayışını ortaya koymayı hedeflemektedir.

Anahtar Kelimeler: Demokrasi, yönetim, profan, meşruiyet.

\section{Giriş}

Din toplumsal bir kurum olarak oldukça önemli bir işleve sahiptir. Onun için dini göz ardı ederek toplumu anlamak oldukça zordur. Aydınlanma düşüncesi ve özellikle bu düşüncenin materyalizmi merkeze alan temsilcileri dini dişarıda bırakarak toplumsal olanı anlamaya ve daha da önemlisi toplumsalı değiştirmeye yöneldiler. Modern dönemlerde dinin etkisinin azalacağ düşüncesi dinin çok önemli olduğunu düşünen yazarlar dâhil herkesin ortak fikri olarak karşımıza çıktı. Ancak paradoksal bir biçimde "din" üzerine yapılan çalışmalar da çok fazla arttı. Sonuçta sekülerleşen dünyada din ortadan kalkmadığı gibi seküler iddialar taşıyan ideolojilere ve politikalara da örneklik teşkil etti. Seküler olan ama dinsel olan yeni düşünce yapıları ve uygulamalar ortaya çıtı.

İdeolojilerin din olarak alınıp alınmayacağı, devletin uyguladığı bazı politikaların dinsel bir form taşıyıp taşımadığı ya da bazı geleneklerin dinsellikle aynı işlevi üstlenip üstlenmediği bu çalışma boyunca tartışmamızı yönlendirecektir. Bunun en önemli sebebi, dinin tanımları üzerinde uzlaşının olmamasıdır. Gerçekten de dinin ne olduğu oldukça tartışmalıdır. Çalışmamızda öncelikle bu konu 
üzerinde durulacaktır ve farklı teorik yaklaşımlardan söz edilecektir. Dinin özellikle kutsalla olan ilişkisi irdelenecek ancak yeri geldikçe ilahi/tanrısal, ruh, sihir/büyü, giz, mana, maneviyat gibi ilişkili kavramlar da kullanılacaktır. "Pür dinsel" bir alan ile "pür profan" bir alanın mümkün olup olmadığı sorunsallaştırılacak ve ortaya çıkan değerlendirmeler 1şı̆̆ında "profan meşruluk" tartışmasına gidilecektir.

Profan meşruluk için seküler olan ancak dinsel bir işlev üstlenen kurumlara bakılacak ve sonuçta profan meşruluğun teorik açıdan mümkün olmasına karşın, pratikte neden uygulan(a)madığına dair tespitler yapılacaktır.

\section{Din Nedir?}

Profan, "din dışı" olanı anlatır. O zaman profan bir meşruluktan söz edebilmek için de dine herhangi bir referans vermeden bir tanımlama yapmalıyız. Ancak "din"in ne olduğu herhangi bir dinin inananları için (en azından içinde bulunulan din açısından) oldukça net gibi görünse de sosyal bilimsel bir kavram olarak oldukça tartışmalıdır. Bu tartışmayı az da olsa aralamak için ve daha sonra ayrıntılandırmak şartıyla, bir giriş mahiyetinde, dinin kutsal olanla ilişkisi olduğu söylenerek başlanabilir.

Rudolf Otto'nun (2014) din ve kutsal arasında kurduğu bağ tam da meseleyi bu boyutu ile anlatır. Ancak siyaset bilimi açısından bakıldığında kutsal dinden çok daha geniş bir kavramdır. ${ }^{1}$ Kutsal olan ama dinsel olmayan söz gelimi bazı ideolojik değerler sayılabilir. Yanı sıra din, sadece kutsalla ilgilenmez kutsal olmayanla da ilgilenir. Örneğin İslam dini her iki dünya saadeti için de öneride bulunmaktadır. Özellikle bu dünyaya ait olan (en azından

\footnotetext{
${ }^{1}$ Bu düşüncenin karşıtı olarak kutsal olanın dinden kaynaklandığı savunulabilir. Örneğin Durkheim, ayinlerden söz ederken kutsama için, onun dini enerji kaynağ 1 ile temas etmesi gerektiğini anlatır (2005: 492). Ancak bu yaklaşım belirli bir dinsel anlayışın (Hıristiyanlığın) yansıması olarak görülebilir. Zira ayinle kutsanan nesneler Hıristiyanlığa uygundur ancak başka dinsel anlayışlarda kutsalın kendinden var olması mümkün olabilir. Bazı dinlerde belli hayvanların kutsallığının kutsanmaya ihtiyaç duymaması buna örnek olarak verilebilir.
} 
bazı dinsel yorumlar düşünüldüğünde) dinin düzenlediği ama kutsal olmayan birçok konunun olduğu söylenebilir. Ama kutsal olanla dinsel olanın bağını koparmak da çok zordur².

Dinsel olan, kutsal olmayanı da belli bir perspektifle görür ve tanrısal bir bağla ilişkilendirir. Bu anlamda din, kutsal olmayanı da kutsalın anlaşılmasında bir araç olarak kullanabilir. ${ }^{3}$ Sonuç olarak din; kutsal düşüncenin kurumsallaşmış hali olarak okunabilir, ancak bu kurumsallaşma "pür" dinsel bir kurumsallaşma olmak zorunda değildir. Örneğin devlet, ideoloji, kimlik gibi kurumsallaşmış yapıların kutsalları da din olarak tezahür edebilir. Bu anlamda "dinsel alan" o kadar büyür ki bu alanın dışında herhangi bir şeyden söz etmek oldukça zorlaşır ve "dinsel" bu kapsayıcılık içinde anlamsız olur. Horton (1960: 205) bu sorunu ele alırken doğası ve varoluş biçimi gereği tüm dinselliği içerecek ontolojik veya epistemolojik bir kavram kullanmanın zorluğuna değinir. Dahası yapacağımız bir dinsellik tanımı da sadece dinsel olanı kapsamakta yetersiz kalacak ve dinsel olanın yanında dindışı konuları da barındıracaktır.

Peki bu söylenenler "pür dinsel" bir alandan söz edilemeyeceği anlamına mı gelir? Ya da bir başka açıdan bakarsak dinin d1şında devlet, ideoloji, kimlik vb. yaşama müdahil olan/anlam katan kavramların ortaya çıkardığ 1 "kurumsal kutsallıklar" 1 dinin dışında mı düşünmek gerekir? Bu soruya cevap verebilmek için "pür din" ile devletten, ideolojiden, kimlikten ya da benzerlerinden kaynaklanan "kutsalı içeren" işlevlerin aynı olup olmadığına bakılmalıdır. Bunun için öncelikle dinin ne işe yaradığına odaklanmak gerekir.

"Dinin işlevi" nedir? Sorusu, aslında dinin ne olduğu ile ilgili tartışmada kendini gösteren din tanımlarından biri ile de yakından ilgilidir. Durkheim'in işlevselci tanımını merkeze alan bu tanımda

\footnotetext{
${ }^{2}$ Durkheim bir inanç sistemi olarak dini kutsalla ilişkilendirir ve bunun tezahürü olarak kiliseyi (dinsel cemaati) görür. Dini, sihirden ayıran özellik onun toplumsal yönüdür. Sihirbaz sadece kendisi ya da ona başvuran birileri için varken din kilise biçiminde somutlaşarak toplumsal bir işlev üstlenir (2005: $64 \mathrm{vd}$ ). Ayrıca bkz. (Hamilton, 2001: 14; Nisbet: 2013: 335 vd.) Profan ise dinsel olanın dışında kurulan cemaat anlamını taşır. (Bkz. Kurt, 2008: 79-80)

${ }^{3}$ Hatta bazı dinsel inançlar kutsal ile profan arasında hiçbir ayrım yapmaya da bilir. Meseleye bu şekilde bakıldığında kutsal-profan ikiliğinin Batı merkezci bir bakışı genelleştirme çabası olduğu da söylenebilir. Hamilton (2001: 16), Goody'nin Batı Afrika'daki çalışmasında ve Evans-Pritchard'ın Kuzey Afrika'daki Azande topluluğu çalışmasında kutsal ve profan ayrımının olmadığına değinir.
} 
dinin ne işe yaradığ din, kişilere yarar sağlar ve bu gerekçeyle de muhafaza edilir. Diğer yanda dinin gerçekte ne olduğuna yoğunlaşan ve dine ait olanı bireysel deneyimlerle algılayan "özsel tanımlar" yer alır. Bu tanımlar dinin özünün ne olduğunu sorarlar ve dinin kutsal, aşkın, ilahi ve tabiatüstü özellikleri ile ilişkilendirilen açklamalar yaparlar (bkz. Kurt, 2008). Edward Tylor'ın "ruhsal varlıklara inanç" (Hamilton, 2001: 14) ya da yukarıda sözü edilen Rudolf Otto'nun “kutsalın tecrübesi" tanımlamaları bu çerçevede görülebilir. Ancak Otto'nun "kutsal" 1 ile Tylor'ın "ruhlar" 1 arasında niteliksel bir fark olduğu da gözden uzak tutulmamalıdır. Zira kutsal; geniş kullanımı ile hemen her dinsel olanla ilişkilendirilebilirken, ruhsal' çimine veya özel bir durumla sınırlandırılabilir. Örneğin İslam açsından ruh ile Şamanizm için ruh kendi bağlamlarında farklılıklar gösterir.

İşlevselci ve özsel bakış açıları neyin din olarak kabul edileceğine dair ortak/evrensel kriterler bulmaya çalışırlar. Bu çaba efradına cami ağyarına mani bir tanım için yetmemektedir. Onun için yapılan tanımlara yönelik ciddi eleştiriler olduğu da göz ardı edilmemelidir. Yanı sıra daha kapsayıc tanım denemelerine de gidilmektedir (Hamilton, 2001: 20 vd.; Kurt, 2008: 81 vd.). Gerçekten de din olarak düşünülen bazı şeyler dışarda kalabilmekte, "din değil" denilen bazı şeyler de kapsanabilmektedir. Bunun çok pratik nedenlerinden biri aslında, "din" ile ilgilenirken aynı zamanda felsefi sistemler, evreni anlamlandırma çabaları, ahlak sistemleri, edebiyat ve diğer sembolik temsil biçimleri ile de ilgileniyor olmamızdır. Bu da dinlerin çok çeşitli tanımlarından söz edilirken aslında birbirinden çok farklı sitemlere din denmesinin, "din" kelimesini flulaştırmasına yol açmaktadır. Ancak herhangi bir ilke veya öz için din denemese de ortak bir ad olarak "din" anlamlı olmaya devam edecektir (Hamilton, 2001: 23).

Bazen de Durkheim'ın dediği gibi din, sadece bir ibadet sistemi değil ayrıca dünyayı açıklayan bir düşünceler sistemi olduğundan dini tanımlamak zorlaşmaktadır (2005: 501). Hatta İslamiyet ve H1ristiyanlık gibi bazı dinler (en azından bu dinlerin bazı yorumları),

\footnotetext{
${ }^{4}$ Tylor'ın kullandığı anlamda "ruh" kavramının sorunlu olduğuna Horton da değinir (1960: 204).
} 
her alanı kapsama iddiasında olabilirler. Örneğin H. Kırbaşoğlu'nun verdiği din tanımlarından biri dini, "dünya görüşü" olarak ele alır. Ona göre bu dünya görüşünü anlatan din , “insana, varoluş, tarih, tabiat ve topluma olduğu kadar, inanç, düşünce, eyle, siyaset, ekonomi ${ }^{5}$, sanat/estetik, hukuk, ahlak, çevre, bilim gibi maddi-manevi bütün alanlara ilişkin kapsamlı ve tutarlı bir akış açısı" sunar. (2010: 22) Ancak şu da unutulmamalıdır ki her bir dini aynı şekilde değerlendirmek de anlamlı olmayacaktır. Örneğin ahlak sistemi önermeyen, daha az gelişmiş dinlerden de söz edilebilir (Hamilton, 2001: $23 \mathrm{vd}$ ).

Literatüre bakıldığında ve yukarıda yapılan açıklamalardan da anlaşılabileceği gibi her çeşit dini kapsayacak bir genel din tanımının yapılamayacağı ortadadır. Ancak her tanımlama çabasının en azından "kutsal" ile ilişki kurduğu görüldüğünden dinin kutsal olmadan düşünülemeyeceği tespit edilebilir. Dinsel olmayan bir kutsalın $^{6}$ varlığı kabul edilebilir olsa da bu tarz bir kutsalın ortaya çıkmasıyla dinsele evrilme olasılığının yüksek olduğu, bu olmasa bile dinselin sınırını sıklıkla işgal ettiği söylenebilir. Örneğin kendisini din karşıtı tanımlayan ancak şehitlik kavramını kullanan bir ideoloji mensubunun ürettiği şehitlik anlayışının profan olduğunu

\footnotetext{
${ }^{5}$ En dünyevi uygulamalardan biri olarak görülen kapitalizmi Protestanlıkla açıklayan Weber, ekonominin dinsel boyutunu ortaya koymaya çalışır. Weber'in çalışmaları "pür dinsel" bir alanın olamayacağına ve/veya pür profan bir alanın olamayacağına dair ilginç veriler sunar. Weber'in Kalvinci Protestan ahlakı anlayışı bir taraftan mistisizmi dışlarken bir taraftan da katı dinsel bir anlayışla insanları sarmalar. Bu dinsel anlayış Tanrının rızasını kazanmak için çalışmayı öncelemekte ve bu öncelikler de Weber'e göre kapitalizmi doğurmaktadır. Herkesin Tanrı karşısında yalnız olduğuna, birey olarak çok çalışmaya ve katı bir kaderci anlayışa dayanan bu yaklaşım ayrıca değişen siyasal düzenin yeni aktörleri için de dünyevi bir meşruiyet alanı açacaktır. Buna karşın, Weber katı bir nedenselcilikle ekonominin dini belirlediği Marksist varsayıma karşı dinin ekonomiyi belirlediği bir düşünceye gitmez. Onun yapmaya çalıştığı ekonomi ve din arasında zaman zaman karşılıklı belirlenimlerin olabileceğidir. Weber'in din sosyolojisi olarak adlandırılabilecek düşüncelerinin bir değerlendirmeleri için bkz. (Aron, 2006: 485 vd.; Nisbet, 2013: $341 \mathrm{vd).}$

${ }^{6}$ Buna karşın Durkheim, kutsal ile profanlık arasındaki ayrımı mutlak olarak görür ve ikisi arasında radikal bir kopuş olduğunu söyler. Her ne kadar ikisi arasında gidiş gelişler mümkün olsa da bu muğlaklıkla ilgili değildir. Sınırlar oldukça keskindir bir sınır geçildiğinde diğeri tamamen terk edilmelidir. (Durkheim, 2005: 57 vd.; Nisbet, 2013: 332 vd.)
} 
iddia etmek çok zordur. Dinsel anlamda şehit olanın "cennete gitmesi" ile ideolojik anlamda şehit olanın "1şıklara yürümesi" niteliksel anlamda aynı dinsel formu taşımaktadır. Onun için profan olanın ürettiği kutsal, onu dinsel alanda her zaman tutmasa da sık sık bu alana itecektir. Aşağıda kutsala yeniden dönüp demek istediğimizi daha çok netleştireceğiz.

\section{Dinin Dini, Bilimin Dini}

İşlevselci, özsel ya da diğer bilimsel tanım demelerine karşın her din de kendini (ve çoğu zaman gerçek din olarak) tanımlar. Bu anlamda bilimsel din tanımlarının yanında dinsel din tanımından da söz edilebilir. Her ne kadar çalışmamız dinlerin kendi tanımlarını merkeze almayacak olsa da kısaca, İslam örneğinden yola çıkarak konuya değinmekte yarar var.

İslami bir perspektifle din, "Allah ile kul ve kullar arasındaki münasebetleri tanzim eden nizam" (Yeğin, 1991) olarak anlatılabilir. Ya da daha geniş bir tanımlama ile "Allah tarafından konulan, Allah'ın gönderdiği peygamberler vâsıtasıyla akıl sâhibi insanlara tebliğ edilen, onlara dünya ve ahiret saadetinin yollarını gösteren hükümler" (Örnekleri ile Türkçe Sözlük, 1995) biçiminde sunulabilir. Bu iki tanımlama İslam'ın (hatta tek tanrılı semavi dinlerin) inanç sistemine uygundur.

$\mathrm{Bu}$ tanımdan hareketle dinsel olanın "Allah tarafından konulan, peygamberler tarafından tebliğ edilen hükümler" olduğu söylenebilir. Bu çerçevede bunların dışında olanları profan olarak kabul etmek ilginç bir kolaylık sağlayacaktır. ${ }^{7}$ Ancak bizim yoğunlaşmak istediğimiz alan "profan meşruluk" olduğu için bu kolay yol işimize yaramayacaktır. Çünkü sorun dinsellik iddiasına profanl1ğın bulaşıp bulaşmadığı değil profanlık iddiasına dinsel olanın bulaşıp bulaşmadığıdır. Onun için bilimsel tanıma geri döneceğiz ve özellikle "dinin ne işe yaradığını" anlamamızı sağlayacak işlevselci

\footnotetext{
${ }^{7}$ Ancak bu kolaycı yaklaşım dinin içinde yer alan farklı yorumları göz ardı etmek anlamına da gelebilir. Örneğin vahdeti vücut açısından bakıldığında kutsal ve kutsal olmayan ayırımı daha bulanıktır.
} 
yaklaşımı yeniden düşüneceğiz ${ }^{8}$. Böylece devlet, ideoloji, kimlik gibi dünyevi fikirlerin dinle aynı işleve sahipse profanlık iddiasını boşa çıarabileceğiz.

İşlevselcilik deyince akla gelecek kaynaklardan biri olan Durkheim, dini anlamaya çalışırken yaptığı tanımlamalarında hem bilimsel olmayı ister hem de çok önemli olan dinin gerçek değerinin anlaşılmasını ister. Bunun için kendisinden önce yapılan teolojik yorumları ve materyalist yorumları aşmayı dener. Özellikle bilimin dine karşı yükselişe geçtiği bir dönemde pozitivizmin önemli temsilcilerinden biri olan Durkheim'ın materyalist yorumu aşma çabası oldukça anlamlıdır. Zira materyalistler dini "idrak ve tasavvurun bir yanılsaması" olarak görüyorlardı (Kurt, 2008: 79). Örneğin Marx "insanı yapan din değil, dini yapan insandır" varsayımından hareketle, dinin bir yanılsamaya yol açtığını, gerçeği ters çevirdiğini ve "halkın afyonu" olarak sahte bir mutluluk verdiğini dile getiriyordu. Ona göre dini ortadan kaldırmaya çalışmak bu yanılsamayı dolayısıyla sahte mutluluğu ortadan kaldırmaya çalışmaktı ki bu da insanların gerçek mutluluğunu istemek anlamına geliyordu (Marx, 2000: 191-192; Nisbet, 2013: 306-307). Bentham da dinde insanı anlamak ve bilime katkı sunmak için herhangi bir özellik olduğuna inanmiyordu (Nisbet, 2013: 305-306). Buna karşın Durkheim, "inananların çağlar boyunca varlığını devam ettiren ortak hislerinin, saf yanılsamalardan ibaret olamayacağı" varsayımından hareket ediyordu (2005: 489). Durkheim için din, dayanışmayı sağlayan önemli bir işleve sahiptir. Bu dayanışma bir bütünleşmeye yol açar ve bütünleşme de ortak his ve düşüncelerin yeniden üretimi ile sağlanır. Bunun için düzenli bir araya gelmeler (ibadetler, törenler, bayramlar, anmalar, kutlamalar gibi) ve tüm bunları organize edecek bir örgüte sahip olmak kaçınılmazdır (2005: 500). Aynı şekilde Durkheim sonrası bir çok işlevselci de dinin; sosyalleşme, meşrulaştırma, anlamlandırma, entegrasyon ve temel varoluş sorunları gibi konularda önemli bir araç olduğunu vurgularlar (Kurt, 2008: 79-80).

İşleve vurgu yapan bazı düşünürler, sosyolojik bakış açısının din olanla-olmayanı ayrıt etmesinin doğru olmadığını düşünürler.

\footnotetext{
8 Tabii ki, diğer din tanımlarını dışarıda bırakmak doğru değildir. Ancak tüm tanımlar kutsalla bağlantılı olduğundan işimize yarayabilir. Zaten kutsal üzerinden konuyu anlamayı tercih ediyoruz. Buna karşın kutsalın deneyimi ve kişisel tecrübelerden ziyade üzerinde konuşmayı kolaylaştıran "işlevi” öne çıkaracağız.
} 
Bu anlamda bütünleşmeyi sağlayan milliyetçilik ve komünizm gibi seküler inanç sistemleri de din olarak kabul edilir (Vrijhof, 1998: 292-293). O zaman dinin işlevine bakılıp seküler olarak inşa edilen devletlerin, ideolojilerin veya kimliklerin dinselliği üzerinde düşünülebilir. Bu dinselliği netleştirmek için de kutsallığa ve kutsallık atfedilen ritüellere bakmak gerekecektir. Bu da bize profanlık iddiası taşıyan inanç sistemlerinin profan olup olmadığını gösteren bir turnusol kâğıdı olacaktır.

Dinin dayanışma, sosyalleşme, meşrulaştırma, anlamlandırma, entegrasyon, bilinmeyeni açıklama işlevi varsa tüm ideolojileri ve kimlikleri din olarak görmek mümkündür. Dolayısıyla devlet (bir ideoloji ve kimlik taşıyıcısı olarak) dinsel bir kurum olarak düşünülebilir. Aynı şekilde dini şekilsel görünürlüğü yani ritüeller ve sembolleri öne çıkararak tanımladığımızda da ideoloji ve kimliklerle olan paralelliği anlaşılabilir. Daha sonra üzerinde duracağımız gibi hem ritüeller hem de semboller konusunda ideolojiler ve kimlikler dinlerden hiç de geri kalmazlar. Hele söz konusu devlet olunca bu ritüeller ve semboller çok daha netleşmekte ve bağlılarınin bunlara uyması ve/veya saygı duyması talep edilmekte, uymama/saygısızlık halleri de çoğu zaman cezalandırılmaktadır.

Ancak tüm bu paralelliklere karşın dinle ideoloji ve kimlikler arasında kurulan bu analoji yeterince tatmin edici de görünmemektedir. Bunun nedeni dinin kutsalının apaçık olmasına karşın ideoloji ve kimliklere ait kutsalın örtük olması ile ilişkilidir. Bunun için din tanımlarına yeniden dönmek ve kutsalla ilişkisini önceleyerek açıklamalar yapmak gerekecektir.

\section{Din ve Kutsal versus Profan}

Hançerlioğlu, Felsefe Sözlüğünde dini “İnanca dayanan doğaüstü tasarımlar ve işlemler sistemi" (1999) şeklinde tanımlar. Doğaüstülük ancak kutsalla bağlantılıysa doğaüstü olarak kalabilir. Aksi takdirde herhangi bir nesne görünenin dışında bir anlam ifade etmiyorsa ona kutsal demek anlamsız olacaktır. Bu anlamda din; görünmeyenle, bilinmeyenle, çözülemeyenle, sırlarla ve metafizikle ilgilenir. Din gördüğün ile yetinmemeyi ögütler. Sır, muamma, hayret ve hayranlık dine inanan insanların ruhunu besleyecektir. Dünyanın bir "büyüsü/gizemi" vardır ve bu "büyü/gizem" ancak din ile 
anlam bulmaktadır. ${ }^{9}$ Bu da maddeden çok mana ile maneviyat ile ilgilenmeyi gerektirir. Bu durumu Durkheim şu şekilde anlatır:

“Bütün dinler hatta en kaba olanları bile, bir anlamda manevidir. Çünkü onların harekete geçirdikleri güçler, özellikle manevi güçlerdir ve aynı zamanda onların temel hedefi de, manevi hayat üzerinde tesir icra etmektir." (2005: 492)

İnsanı aşan manevi güçler kutsalı anlatır ve kutsal da tam da burada devreye girmektedir. Meseleye bu şekilde bakılınca tüm din tanımlarında kutsal sezilebilir. Din "kutsal" ın üzerine bina edilmiştir ki "kutsal" kelimesinin Osmanlıca'daki karşılıklarından biri de "dini"5 yani dinle ilgili olandır. O zaman kutsal kelimesinin tanımlanması bizi aydınlatacaktır.

Kutsal, tapınılacak derecede saygı duyulan şeydir. Değişimin dışında görülür, dokunulmaz ve tartışılmazdır. Ermiş ve kutlu anlamında da kullanılır, bu anlamda tanrisal olan ya da tanriya yakın olanı dile getirir (Hançerlioğlu, 1999). Kutsal, aşkın, mutlak hakikat, "sıradan insan düşüncesinin anlayış ve kavrayış gücünden kaçan şey"7 olarak karşımızda durmaktadır. Durum böyle olunca "kutsal" tam da N. Nisbet'in anladığı anlama ulaşmış olur: mit, ritüel, ayın, dogma, davranışlarda bulunan töre, "faydacı ve rasyonel yönelişleri aşan" "bireysel motivasyon" ve "sosyal örgütlenme" alanları anlamında "karizma" ve "dini adayış" (Nisbet, 2013: 301). Bu tanımlamaların aslında "profan" için ne anlam ifade ettiği (en azında teorik açıdan) oldukça açıktır: hiç bir şey.

Ancak bizim üzerinde duracağımız asıl konu, profan olan (ya da olduğu söylenen) devletin acaba dinin dışında mı yoksa o da bir nevi din tanımlamasının içinde mi bir meşruluğa başvurduğudur. Çünkü tanımımızda yer alan "değişmezlik, dokunulmazlık, tartışılmazlık," niteliklerinden arınmış bir yönetimin ne derece gerçekleştirilebildiği tartışılabilir. Yani açıklığa kavuşturulması gereken nokta kutsalı olmayan bir devletin olup olmadığıdır.

Din büyülü bir kutsallıkla örülüdür buna karşın profan olan bu büyüyü bozduğu ve gizemi çözdüğü iddiası ile yola çıkar. Profanlık mevcut dinselliği yok etmeye çalışır ve ruh yerine bedeni koyar, görünmeyene karşlık görülenle yetinir, çözülemeyenle ilgilenmez ve

${ }^{9}$ Bu çerçevede bir değerlendirme için bkz. (Kırbaşoğlu, 2010: 21 vd). 
çözebildiklerini merkeze alır. Bu anlamda asıl hedef kutsalı ortadan kaldırmaktır.

Bu çerçevede paradoksal bir biçimde sosyologların yoğun kutsal ve din ilgilerine ${ }^{10}$ rağmen modernlikle birlikte kutsalın ortadan kalktığı ve/veya etkisinin azaldığ ${ }_{1}$ savı oldukça güçlüdür ${ }^{11}$. Örneğin Weber eski çağların kutsallıkla dolu olduğunu yani o dönemlerde karizmanın ve olağanüstülüğün anlamlı olduğunu ancak modern çağda büyüden kurtulmanın söz konusu olduğunu dolayısıyla akılc1lığın ve olağanın anlamlı olduğunu iddia eder. Böylece büyüsü bozulan bir dünyada da dinin ancak bireysel vicdanlarda yer bulacağı düşüncesi öne çıkar (Aron, 2006: 499). Comte, bilimsel aşama ile birlikte dinseli ve metafiziği anlatan "gizemleştirmenin" yok olacağını düşünür (Giddens, 2006: 357). Durkheim ise akıl ve iman arasındaki bir zıtlığın modern dönemlere kadar hiçbir şekilde yüzde yüz olmadığını belirtir ancak "eğer onların farklılığının açık bir şekilde göze çarptığı bir an tarihte var olmuşsa, o an işte bu andır" der. Ona göre "bilimsel düşünce, dini düşüncenin yalnızca daha mükemmel bir şeklinden ibarettir. Bundan dolayı, bilimin bu görevi yerine getirmek için gittikçe daha uygun bir hale gelindiğinde, dinin zeminini kaybetmesi normal gibi görünmektedir" (2005: 502).12 Weber, Comte ve Durkheim örneklerinde olduğu gibi modern sosyolojik düşünceyi üreten düşünürler gibi aydınlanmacı ve modernist düşünürlerin genel anlamda kutsallığın ortadan kalkacağına ve/veya etkisinin azalacağına/farklılaşacağına ve dünyanın büyüsünün bozulduğuna (veya daha az büyülü alanın kalacağına) bir inançları vardır. Peki kutsalı ortadan kaldırmak (en azından politik düzende) acaba mümkün müdür?

Bir başka soruya daha ihtiyaç vardır. "Kutsalı ortadan kaldırma hayali ile yola çıkan insanların profan olarak ortaya koydukları gerçekten de profan mıdır yoksa yeni kutsallıklar mı üretilmektedir?" Politik alan ile ilgili bu soruyu sormak çok daha

\footnotetext{
${ }^{10}$ Sosyologların din ve kutsa olan ilgileri hakkında bkz. (Nisbet, 2013: 302-303).

${ }^{11}$ Nisbet'in Aydınlanma bağlamıyla konuyu ele alışı için bkz. (Nisbet, 2013: 304)

${ }_{12}$ Ancak Durkheim için bu zemin kaybı dinle bilim arasında bir mutlak uzlaşmazlığın olduğu anlamına gelmez. Bilim dinin var olma hakkını tartışma konusu yapmaz. Sadece eşyanın tabiatı ve dünyayı açıklama tarzını kabul etmez ve dinin bu alandan çekilmesini talep eder (2005: 503).
} 
yerinde olacaktır. Zira modern devletlerin laiklik/sekülerlik vurguları kuşkusuz çok güçlüdür ve bu iddia profanlığın devlet düzeninde uygulanabilirliğini savunmaktadır.

Fransa ve Türkiye gibi laiklik vurgusunu dinin kamusal alandan tamamen dışlanması biçiminde algılayan pratikler, insanlık tarihi kadar eski olan dinsel meşruluğu bir kenara bırakmayı çok arzulamışlardır. Aslında bu arzunun çok pratik bir nedeni vardır. Eski yöneticilerin yerini almak isteyen yeni yöneticiler (krallık ve padişahlık yerine cumhuriyete geçiş) eskinin güçlü dinsel meşruluğunu sürdüremezlerdi. Yüzlerce yıllık bir birikimle olgunlaşan dinsel meşruluğun ne olduğuna ancak eski düzene bağlı dini yorumlama gücüne sahip din adamları/ulema yapabilirdi. Bu kişilerin yapacağ 1 yorum, eski yönetimin yerine yeni bir yönetimi öngörmeyecek, dolayısıyla yönetimin el değiştirmesini meşrulaştıramayacaktı. Kullanılacak her yetki, eskinin gölgesinde kalmayı sağlayacaktı. Yapılması gereken bu tarz bir yorumcu kitlesi de dâhil olmak üzere eskiyi yerle bir etmekti. Eskiyi yorumlayanlar olmayacaksa ve/veya sesleri kısılacaksa yeni bir meşruluk kaynağı kurulabilir ve bu meşruluk kaynağına uygun yorumcular ortaya çıkabilirdi. Aydınlanma düşüncesinin birikimi özellikle Fransa'da buna hazır bir seküler aydın grubu da oluşturmuştu. Bu grup, Türkiye gibi henüz seküler yolun başında olan dünyanın farklı coğrafyalarından toplumlara da düşünce ihraç edecek donanımdaydı.

Dönemin olgunlaşan devlet yapısı, modern ulus devletler, dinsel olanın yerine seküler olanı koymaya çok elverişliydi. Çünkü Tanrı'ya dayandırılan egemenliğin kullanımı dolayısıyla tanrısal bir gücü kullanmak ancak Tanrı adına konuşmaya yeterli kişilerin tekelinde olabilirdi. Gelişen burjuva sınıfı bu denklemin içinde parası olan ancak politik bir gücü olmayan bir figüranın ötesine geçemezdi. Tam da burada ulus devlet, ulusu kutsallaştırarak bir tanrısal figür haline getirebilirdi. Egemenliğin Tanrı'dan alınıp ulusa aktarılması düşüncesi bu ihtiyacın bir tezahürü olarak okunabilir. Artık aydınlanma felsefesiyle düşünce planında gerçekleşen, sanayileşme ile birlikte kozmopolitleşen toplumun dinsel çokluğu karmaşa olarak kodlanan ve modern bilim ile olabilirliği delillendirilen profan bir dünya inşa etmek çok daha mümkün görünmektedir. Bunun siyasi ayağı da şüphesiz ulus-devletler olacaktır. 
Devlet tarzlarının hemen hepsinde olduğu gibi ulus devletlerin de gerek kuruluşlarında ve gerekse işleyişlerinde, daha sonra da değineceğimiz gibi, "kutsal olan”ı içerdiğini görüyoruz. Günümüz açısından ulus-devlet önemli olduğundan, ulus-devlet içindeki kutsal öğelere daha çok değinmek yararlı olacaktır. Ulus devlet öncesinde ve eğer olacaksa sonrasında da iktidarların kutsalla başvurmaları işlerini kolaylaştıracağından kaçınılmaz görünmektedir. Dolayısıyla laiklik/sekülerlik iddiasındaki devletlerin profan olması gereken tüm işleyişlerinin ulus-devlet olma sürecinden kaynaklanan ve ulus devletin sürdürülmesi şartlarından dolayı hiç de profan olamayacağı görülüyor. Bazı teoriler ve uygulamalar kutsalın ne kadar önemli olduğunu fark edip kurdukları dünyevi düzeni güçlendirmek için kutsaldan yararlanmayı da denemişlerdir. $\mathrm{Bu}$ alandaki bazı örneklere değinmek daha sonra üzerinde duracağımız "profan meşruluğu" anlamak için de gerekli olacaktır.

\section{Modern Çağlarda Kutsalı Yeniden Üretmek}

Modern dönemlerde ilginç bir biçimde "yeni din" inşa etme girişimleri ile karşılaşıyoruz. Aslında oldukça seküler olan bu düşüncelerin temel kaynağı dinin toplumda önemli bir kurum olmasıdır. Bu önemli kurumun sökülüp atılamayacağı, insanların inanma ihtiyaçlarının olduğu ve bu ihtiyacın giderilmesinin toplumsal bir yarar da sağlayacağ 1 düşünüldü. Sonuçta 'mevcut dinler, insan aklına çok uymadıklarına göre kendi dinimizi kendimizin icat etmesi çok daha anlamlı olacaktır' düşüncesine varıldı.

Bu bakış açısı her ne kadar profan bir başlangıca sahip olsa da açık bir biçimde profanlıktan ayrılmaktadır. Kutsala olan ihtiyaca vurgu yapmakta ve insan eliyle kutsalı yeniden icat etmenin yollarını aramaktadır.

Bu konuda akla gelebilecek ilk örnek J.J. Rousseau'nun "sivil din/toplum dini/yurttaşlık dini" düşüncesidir. Onun ortak çıarları koruma düşüncesi sivil dinin temelini oluşturur. Bu din, bireysel ve grupsal çıkarların topluma hâkim olmasını engelleyecek bir mekanizma gibi düşünülür. Anlaşılacağı üzere Rousseau'nun kaygısı 
toplumsal bütünlüğü korumaktır bunun için de "sivil din" anlay1şını politik bir araç olarak kullanmak ister (2006: s. 124 vd.). ${ }^{13}$ Toplumun bütünlüğü için dinin gerekli olması "temelinde din olmayan hiçbir devletin kurulmadığı" düşüncesi ile temellendirilmektedir. Ayrıca Hıristiyanlığın bu bütünlüğü yeterince sağlayamayabileceği (2006: 129) onun Hıristiyanlık yerine neden Sivil Din'i önerdiğini de anlatır $^{14}$

Fransız Devrimi süreci yeni "din icadı" konusunda ilginç tartışmalar da doğurmuştur. Devrimin toplumsal hafızayı yok edip, yeni bir düzen kurma isteği onun en önemli toplumsal hafıza taş1yıcılarından biri olan dine de müdahale etme isteğini beraberinde getirmiştir ${ }^{15}$. Yanı sıra Devrime din kaynaklı eleştiriler çoğalınca, devrimcilerin Hıristiyanlığa özellikle Katolikliğe yönelik tepkileri de artmıştır. Bu tartışma Hıristiyanlıktan ayrılma ve devrime uygun bir din oluşturma düşüncesine kadar varmıştır. Kiliseye karşı tedbirler alınmış, dinin kamusal görünürlükleri ortadan kaldırılmıştır. Kiliseler işlevlerinin dışında da kullanılmaya başlanmıştır. Pazar gününün tatil olmaktan çıkarılması ve bazı bölgelerde kiliselerin kapatılmasına varan girişimler Hıristiyanlıktan çıkma denemeleri olarak karşımıza çıkmaktadır (Nisbet, 2013: 304-305). Ancak bu çaba Hıristiyanlık yerine yeni bir din getirme düşüncesini de beraberinde getirmiştir. "Özgürlük Şehitlerine Tapınma" olarak adlandırılan bu anlayışın dinsel bir form olduğu söylenmelidir. Görkemli şenlikler, ulusal günler, özgürlük şehitlerinin anılması tıpkı Katolik anmaları hatırlatmaktadır. Ayrıca kapatılan kiliselere, Hıristiyan azizlerinin

\footnotetext{
${ }^{13}$ Ayrıca Rousseau'nun "sivil din" düşüncesi ile ilgili bkz. (Duman, 2010b; Orhan, 2013).

${ }^{14}$ Rousseau'nun Hıristiyanlığa vermediği “sivil din" payesini, Tocqueville Amerika bağlamıyla verecektir. Rousseau, Hıristiyanlığın hoşgörü üretmediği için bütünleşmeyi sağlayamayacağını düşünüyordu. Oysa ki Tocqueville, Amerika demokrasisi açısından Hıristiyanlığın çok önemli bir işlevi oluğunu düşündü ve "sivil din" olarak işlev gördüğünü iddia etti. (Turner, 1998: 238). Tocqueville'nin bu düşünceleriyle paralel bir saptaması da Amerika'daki din temsilcilerinin siyasal bir güçle ittifak kurmama konusunda oldukça hassas davranmalarıdır. Bu, kilise ve devlet işlerinin ayrı düşünülmesi ile ilişkilidir. Buna karşın Avrupa'da ittifaklar görülür ve bu da dini yıpratan bir etki ile sonuçlandığından, dinin Amerika'daki işlevi ile Avrupa'daki işlevi aynı değildir. (Nisbet, 2013: 322-323.)

${ }^{15}$ Toplumsal hafıza ve Fransız Devrimi konusunda bir çalışma için bkz. (Duman, 2010c).
} 
yerine devrim şehitlerinin resimleri, heykelleri konuyor, insanlar bu dinin kurallarına uysunlar diye zorlanıyorlardı (Kılıç, 2007: 32) .

Fransız Devrimi'nin önemli gruplarından olan ve kısa bir dönem iktidarı elinde bulunduran Jakobenlerin bazı temsilcileri ise "akıl dini" ni önerdiler. "Akıl dini" Milli Devrim Meclisi tarafından resmi olarak da kabul edildi. Yeni dinin ibadethanesi "akıl tapınağ1" ve tanrısı ise "Yüce Varlık"tı. İnsanların Yüce Varlık'a karşı sorumlulukları düzenlenmişti ve yeni dinin bayramları belirlenmişti. Bu din temelde vatan sevgisi ve cumhuriyetçiliğe dayanıyordu (Kılıç, 2007: 35).

Görüldüğü gibi modern devletlerin ürettiği din anlayışının öncülüğünü Fransız devriminde aramak yanlış olmayacaktır. Bu konuda Durkheim'ın tespitleri de bu yargıyı güçlendirecek mahiyettedir.

"Hiçbir yerde, toplumun kendisini tanrılaştırması ya da
tanrılar yaratması yeteneği, Fransız devriminin ilk yılla-
rında olduğundan daha açık olmamıştır. Gerçekten de,
bu zamanda, genel heyecan ve galeyanın etkisi altında,
doğaları gereği saf laik, dini olmayan şeyler, kamuoyu ta-
rafından kutsal şeylere dönüştürüldü: Vatan, Özgürlük,
Akıl. Bir din, kendiliğinden kurulma eğiliminde oldu.
Onun dogmaları, sembolleri, mihrapları ve bayramları
vardı. Akıl ve Yüce Varlık ibadetinin bir tür resmi tatmin
sağlamaya teşebbüs ettiği bu kendiliğinden ortaya çıan
arzulardı." (2005: 262)

Fransız Devrimcilerinin dine karşı bu tutumunu devlet ve kilise arasında bir bütünleşme olması gerektiğini savunan E. Burke eleştirmiştir. Ona göre istikrarlı bir siyasal düzen için bu kaçınılmazdır. Din, devletin keyfi yönetimi için bir engel teşkil edecek ara kurumlar anlamına gelmektedir. Böylece Burke, kilise ve din adamlarının toplumsal düzendeki yerini vurgulamak ister, bir adım daha ileri giderek devletin meşruiyeti için hem devletin hem de yöneticilerin, "devletin dinsel kurumu" tarafından "kutsanması" gerektiğini söyler. Tüm bunlar Burke'ün devletin karşısında kilisenin üstünlüğünü vurguladığı anlamına gelmez (Duman, 2010a: 470471). Aslında onun yapmaya çalıştığı bir nevi "sivil din" olarak dinin/kilisenin devletin keyfi iktidarını sınırlama konusunda bir işlevi 
olduğunu vurgulanmaktı. Burke'ün bu düşüncesi, dinsel bir düşüncenin tezahürü olmayıp dünyevi ihtiyaçların bir tezahürü olduğundan, modern dönemde kutsala bir işlev vererek yeniden üretmeye de örnek teşkil etmektedir.

Burke'ün aksine Fransız Devrimini olumlayan ancak aydınlanmanın din anlayışına ciddi eleştiriler getiren Tocqueville (Nisbet, 2013: 317 vd.), devrim ve din konusunda oldukça önemli bir konuya dikkat çeker. Ona göre Fransız Devrimi, siyasal bir devrimden ziyade dinsel bir devrimle karşılaştırılabilir özelliktedir. Tocqueville bu iddiasını Devrimi Hıristiyanlık ve İslam gibi dinlerle karşılaştırarak açıklamaya çalışır. Devrim, dinler gibi uzaklara yayılmayı hedeflemekte sadece kendi sınırları dâhilinde değil, vaaz ve propaganda yoluyla başka sınırların da içine girmektedir. Dinler insan doğasına uygun olduklarını söylerler ve her yerde her zaman uygulanabilecek kurallar vaaz ederler. Örneğin Hıristiyanlık başarısını tek bir halka ya da ülkeye hitap etmekle kazanmamış aksine sınır tanımayarak başarılı olmuştur. Devrim de bu yolda ilerlemiş "askerleri, havarileri ve şehitleriyle" bütün dünyaya yayılmıştır (Tocqueville, 1995: 49 vd). Görüldüğü gibi hem Devrimin ideologları ve uygulayıcıları bilinçli bir şekilde din icadı ile uğraşmışlar hem de devrimin yankısı ve algılanışı bir din biçimini almıştır.

Seküler olanı dinselleştirme konusunda birçok kişi tarafından sosyolojinin kurucu babası olarak görülen Comte'un çabası da dikkate değerdir. Comte açıkça bir din kurmaya niyetlenmiş ve kendisini de bu dinin büyük papazı olarak görmek istemiştir. Sosyoloğun ruhları eğiten barışçı bir peygamber işlevi üstlenmesi onun bu düşüncesini yansıtır. Amacı bilim adamlarının koyduğu yasaların dogma olarak algılanıp çokça tartışılmamasıdır. Onun için bilim adamları bu dinin öncüleridirler. Bu insanlık dinidir ve insanları "Büyük Varlık"1 sevmeye davet eder. Büyük Varlık, "insanların sahip oldukları ya da yaptıkları en iyi şeylerdir". Comte'un dini pozitivist bir etki taşır. Onun için geçmişte yaşayan dinlerin dişındadır. Geçmişteki dinler artık geçerliliği olmayan bir düşüncenin ürünü olduklarından, pozitivist dönemin bilimsel düşüncesine sahip insanlarını etkileyemezler. Ona göre vahiy ya da tanrısallık artık inanulacak değerler değildir (Aron, 2006: 108 vd.; Nisbet, 2013: 310 vd.). Bu saptamalar eğer yeni bir din kurma düşüncesi olmadan sadece bilimsel gelişimin insan üzerindeki etkisi biçiminde düşünülürse 
birçok materyalistin düşündüğü ile paralel bir sonuç doğururdu. Ancak Comte dini bir yanılsama ya da bilincin ters çevrilmesi olarak görmez aksine insanların dine ihtiyaçları olduğunu ${ }^{16}$ düşünür ve oluşan yeni aşamada bu dini kendi belirlemek ister.

Yukarıda sıraladığımız bilinçli "din" olarak üretilen modern fikirlerin yanı sıra ideolojilerden ve devlet sistemlerinden de söz edilerek dinsel bazı formların üretildiği görülebilir. Öncelikle liderlerin ve ulusal figürlerin kutsallaştırılması (bir nevi Tanrılaştırma, peygamberleştirme, azizleştirme, evliyalaştırma olarak görülebilir) sıklıkla başvurulan bir yöntemdir. Durkheim bunu şu şekilde dile getirir.

"Eğer toplum, bir adama vurulmuşsa ve onu harekete ge-
çiren en derin arzular ve bu arzuları tatmin etme vasıta-
larını onda bulduğuna inanıyorsa, o zaman bu insan,
diğerlerinin üstüne yükseltilecek ve adeta tanrılaştıracak-
tır. Kamuoyu ona, tam olarak koruyucu tanrılara verdi-
ğine benzer bir haşmet verecektir. Bu, yaşadıkları çağın
kendisinde bu tür niteliklerin bulunduğuna inandığı bir-
çok hükümdar hakkında olan bir şeydir: Eğer onlar, tanrı
yapılmamışlarsa bile tanrının doğrudan bir temsilcisi ola-
rak kabul edilmişlerdir... Üstelik insanın getirildiği bu
yüksek toplumsal konumların aldığı saygı, nitelik olarak
dini saygıdan farklı değildir. Bu, benzer hareketler tara-
fından da ifade edilir: Bir insan, yüksek bir şahsiyete sa-
hip olan birinden uzak durur; ona yalnızca, bir takım
tedbirler aldıktan sonra yaklaşır; onunla konuşurken, sı-
radan ölümlülerle konuşurken kullandıklarından başka
mimikler ve başka bir dil kullanır. Bir insanın bu şart-
larda hissettiği dini hisse o kadar yakındır ki, birçok
kimse bu iki hissin arasını ayıramaz. Sahip oldukları hu-
susi saygı ve hürmeti açıklamak maksadıyla, prenslere,
asilzadelere ve siyasi liderlere kutsallık atfedilir." (2005:
261)

Toplumlar sadece insanları değil fikirleri de kutsallaştırır. Dinsel yasaklara paralel yasaklar da getirir, seküler yaşam tarzı ve yaşama bakış açısına eleştirilere karşı tahammülsüzlük de gösterir. Durkheim bu konuya da açılık getirir:

${ }^{16}$ Din ihtiyacı, Comte için "insanın kendisini aşan bazı şeyleri sevmeye ihtiyacı" olduğundan vardır (Aron, 2006: 114). 
"Bir inanç bütün toplum tarafından ittifakla paylaşıld1ğında... onu reddetmek ya da onun yanlış olduğunu göstermeye çalışmak yasaktır. Eleştiriye yönelik yasak, başka herhangi bir yasak gibidir ve bir kimsenin kutsal bir şeyin huzurunda olduğunu ispat eder. Hatta bugün, başkalarına verdiğimiz özgürlük ne kadar büyük olursa olsun, bütün olarak ilerlemeyi reddeden ve modern toplumların bağlı bulunduğu insani ideal ile alay eden bir adam, kutsal şeylere saygısızlık etkisi meydana getirir." (2005: 261-262)

Din üretim ihtiyacı başlı başına üzerinde düşünülmesi gereken bir mevzudur. Birçok açıdan ele alınabilecek böyle bir konu bu çalışmanın sınırlarını aşmaktadır. Ancak şu söylenebilir ki bu üretim ister mevcut/kadim bir din adına olsun ister üretilmek istenen/seküler bir din adına olsun insana ait bir ihtiyacın hissedilmesi ve bunun giderilmesi ile ilişkilidir.

Bu çerçevede Aydınlanma ve Fransız devrimine karşı oluşan ve dini yeniden öne çıkaran güçlü bir akımın olduğu da gözden uzak tutulmamalıdır. Bu akımı sosyologlar açısından değerlendiren Nisbet, dinle ilgilenen sosyologların dört farklı perspektifle yaklaşılabilecek gerekçeleri olduğunu düşünür. Bunlar dinin; (1) toplum için zaruri olması, (2) tarihin ve sosyal değişimin anlaşılmasında önemli bir rolünün olması, (3) ayin, seremoni, cemaat, otorite, hiyerarşi ve organizasyon gibi dini anlatan kavramların gösterdiği gibi dinin sadece inanç, doktrin ve idrakten ibaret olmaması ve (4) insan düşüncesinin temel kaynağı olduğuna dair bilinçli bir çaba ile oluşan yeni bir akımın oluşmasıdır (2013: 312-315).

\section{Meşruluk: Dinsel, Profan ve Sentez}

Bütün yönetimler, hatta diktatörler bile, kendilerinin meşru yollardan iktidara geldiklerini ve yine meşru bir biçimde yönettiklerini iddia ederler. Bu da bize meşruluğun ne kadar önemli bir işlev gördügünü gösterir. Bu kadar önemli bir konuda, bazı tutarsızlıklar ciddi sorunlara neden olabilir. Konumuz bağlamında profanlık iddiası ile yola çıkan ancak kutsalı yeniden üreten bir meşruluk anlayışının sorunlu olduğu en azından söyledikleri ile yaptıklarının aynı olmadığı dolayısıyla ahlaki bir çelişki yaşadığı üzerinde durulacaktır. Örneğin laiklik ve/veya sekülerlik tanımı gereği “din dışı 
(profan)" olmak zorunda. Ama uygulamalara bakıldığında, sanki farklı bir dinmiş gibi algılanabilmektedir.

Profanlık iddiasının önemli yansımalarından biri olan laiklik, çok genel anlamda "...bu dünya ile öte dünyanın birbirinden ayrılmaları, farklılaşmaları ve birbiriyle olan kesişme terimini küçültmeleri, limitte yok etmeleri..." (Kılıçbay, 1994: 20) biçiminde tanımlanabilir. Bu tanım oldukça yaygın bir kabul görür. Ancak ciddi sıkıntıları da beraberinde getirir. Öncelikli olarak bu dünya-öte dünya tanımlamalarını kesin sınırlar ile belirtmek mümkün müdür? Burada yukarıda yapılan din tanımları hatırlanmalı ve bu dünyanın dinsel yönünün de olduğu, hatta dünyevi dinlerin de olabileceği hatırlanmalıdır. Durum böyle olunca "din ve devlet işlerinin birbirinden ayrilması" tanımı da ciddi problemli hale gelir. Bu ayrımı bir an kabul etsek bile problem, sadece din savunucularının devleti dinselleştirmeleri ile ilgili de değildir. Ayrıca seküler olanların da devleti dinselleştirmeleri ile ilgili bir problemdir. Durum böyle olunca din işleri ve devlet işleri bir birlerine karışmaktadır.

Profanlığ1 savunanların devleti dinselleştirme isteklerinin nedeni sorgulanmalıdır. Aslında bu sorunun oldukça pratik bir ihtiyacı gideren bir yanıtı var. Kutsallığın; insanların (buna inanmaları ölçüsünde) saygı ile bağlandıkları ve doğaüstü güçler atfettikleri, aklın açıklamada zorlandığı inanışlar içermesinden dolayı, meşruluk aracı olarak kullanılması yöneticilerin işlerini oldukça kolaylaştırmaktadır. Dolayısıyla meşruluk arayışında iktidarların, kolaycıllğı seçip, laik meşruluğun dışında "kutsallar içeren" meşruluk yollarına başvurmaları kendileri açısından anlamlı görünmektedir. Ancak bu anlam kutsalın üretimi ile insanı aşmakta adeta başka güçlerin insana hükmettiği olağanüstü bir ruh haline neden olmaktadır. Dünyevi olarak üretilen bu yeni kutsal alan, insanlara başka kutsallıkların üretilebileceğini de gösterir. Her bir kutsallık üreticisinin gücüne güç kattığı görüldükçe de yeni kutsallıklar üretmek isteyenler çoğalacaktır. ${ }^{17}$ Kutsallık üreticileri tıpkı kadim dinsel dönemlerde görüldüğü gibi kutsallıklarını savaştıracaklardır. Bü-

\footnotetext{
${ }^{17}$ Fransız Devrimi sonrasında rakip devrimcilerin ürettikleri ve karşı çıktıkları dinsel anlayışlar bu durumu en iyi şekilde anlatmaktadır.
} 
tün bunların sonucunda dünya yeni bir büyülenme dönemine girmiş olacaktır. ${ }^{18}$ Ancak bu dünyevi kutsallıklar da ister istemez kutsallığın gerçek kaynağı olan kadim dinlere geri dönüşü sağlayacaktır. İdeolojilerin ve/veya meta anlatıların sonundan söz edilen bir dönemde dinlerin yükseliş (her ne kadar eski formlarıyla olmasa da) tam da bu durumu anlatmaktadır. Şimdi meşruluğun farklı kaynakları üzerinde durup konuyu biraz daha açabiliriz.

Meşruluk yönetme hakkıyla ilgili bir kavramdır. Ancak "yönetmek benim hakkımdır" demekten çok "yönetmek senin hakkındır" denmesiyle ilgilidir. Yani başkalarının yönetimi ve/veya yöneticiyi haklı görmesi meşruluğu anlamlandırır. O zaman Münci Kapani'nin dediği gibi "rastgele elde edilmeyip bir hakka dayandığı fikrinin kabul edilmesi ölçüsünde" bir iktidar meşru olur (Kapani, 1998: 67).

Meşruluk ile iktidar, otorite ve yasallık arasında da sıkı bağlar var, bazen birbirlerinin yerine kullanılsalar da çoğu zaman bunları birbirinden farklılaştırmakta yarar vardır. ${ }^{19}$ Kısaca yasallık, yasaya uygunluğu anlatır ancak bu dayanağın rıza ile kurulmasını garanti etmez. Yani her yasallık meşru bir kaynağa dayanmayabilir.

Bunun yanında iktidar, bir şeyi birisine yaptırtma gücü, otorite ise bu gücün meşru kullanımını anlatır. Dolayısıyla, çok genel anlamda, iktidarın sosyoloji otoritenin de felsefi boyutta olduğu söylenebilir (Barry, 2004: 95). Aslında bu ilişkide, L. Lioson'un tabiri ile yönetim, "iktidarı otoriteye" dönüştürmeye çabalar, yönetilenler ise ihtiyaçlarını giderecek bir otoriteye sahip olmayı isterler. Otorite oluşturmada otoritenin, kullanıcıların doğuştan getirdiği bir haktan kaynaklandığ 1 söz konusu olabileceği gibi yönetilenlerin verdiği bir yetki olarak da görülebilir. İlkinde genellikle bir azınlığın kendinde gördüğü üstünlükleri öne çıkarması ve bunu geri kalanlara empoze etmesi söz konusudur. Bu durumda yönetilenler itaat eder ve yönetime karşı sorumlu olurlar. İkincisi ise demokratik anlayışa daha uygundur. Yönetenlerin yönetenlere hesap verme zorunluluğu var-

${ }^{18}$ Milliyetçilerin ve komünistlerin ideolojik savaşlarında şehitlikten ve uğrunda ölünen kutsal davalardan, şeytanlaştırılmış düşmandan söz etmeleri bu durumu anlatır.

${ }_{19}$ İktidar, otorite, yasallık ve meşruluk kavramlarının genel hatları ile ele alındığı bir kaynak için bkz. (Heywood, 2012). 
dır. Yönetim çoğunluğun rızasını almak zorundadır. "Çoğunluğun" ne olduğu ve iradesini nasıl ifade edeceği tartışllsa bile çoğunluğun rızasını almak diktatörlüklerle demokrasileri ayıran bir ilkedir. Yanı sıra otoritenin kaynağı, yönetilen insanların dışında, dışsal olabileceği gibi içsel kriterlerle de kurulabilir. Dişsallık özellikle Tanrı, silahlar (güç) ya da atalara dayandırılır. Ancak içsel kriterler içinde seçkinlere (yaşll, bilge, zengin vb.) bir hak formüle edilebilir ya da çoğunluğun istediği ile hareket edilebilir (2005: 197 vd.).

Yönetimin talebine karşın yönetilenlerin bu talebi haklı görmesi süreç için olumludur. Görüldüğü gibi meşruiyet gücün dayanağı ile ilgilidir. Bu dayanak insanların rızalarını oluşturduğundan toplumsal düzenin sürdürülmesi için hayati bir önem taşır. Dolayısıyla otoritenin kullanımı ve yasaların dayanaklarının meşruluk ile şiddetten daha çok rızaya dayanması sağlanmadığı sürece toplumsal düzeni belki kurmak kolay olabilir ancak sürdürmek oldukça zor olacaktır. Buradan yola çıkarak tarihin değişik aşamalarında farklı ihtiyaçlar ve durumlar karşısında farklı meşruluk anlayışlarının olduğunu söylemek gerekir. Biz çok genel anlamda meseleye yaklaşıp ikili bir ayrıma gideceğiz; dinsel meşruiyet ve profan meşruiyet.

\section{Dinsel Meşruluk}

Dinsel meşruiyetin temelinde, insanın varoluşunun kendi dışındaki varlıklara bağlı olması düşüncesi vardır. Bu varlıklar özellikle dinsel olanın kurucu unsurları olarak karşımıza çıkarlar. Tanrı/tanrılar veya olağanüstü güçlere sahip kurucu atalar (yukarıda sözü edilenler çerçevesinde düşürsek kutsalın kaynakları) birçok dinsel formun temelini oluştururlar. İnsanı var eden bu varlıklar ayrıca insanların bir arada yaşama düzenleri ile ilgili bir şeyler de talep ederler. İşte bu talep, insanın "borcu" bu varlıkların da "alacaklı" olduğu bir düzeni ortaya çıkarır. Borçluların alacaklıların rızasını gözettikleri noktada "meşruiyet" fikrine de ihtiyaç duyulmaktadır. Toplumsal düzen bizi var edenin rızasına uygun olmalıdır. Zira kendi varoluşu hakkında söz söyleme hakkı olmadığını düşünen ve varlığının meşruiyetini doğaüstü bir varlığa bağlayan toplum, içinde yaşadıkları örgütsel yapı hakkında bir söz haklarının olmadığını düşüneceklerdir. İşte bu düşünce, tam da devleti doğuracak bir düşünce olarak 
karşımıza çıkar (Gauchet, 2000: 34-35). Bundan sonraki temel mesele oluşturulan devletin borçlu olunan varlıkların istediği bir yapı olup olmaması olacaktır. Eğer oluşturulan yapı alacaklıların istediği bir yapı ise şüphesiz bu durum "meşruiyeti" sağlayacaktır.

Siyasal iktidarın meşruluğu konusunda Mısır firavunlarının bulduğu formül ilginçtir. Bu formül kralı tanrısallaştırarak "alacakl1" konuma getirir ve ödenecek "borcun" ne olduğuna dair tek söz de onun olmuş olur. Bu, her yönetimin arayıp da bulamayacağ 1 ama fırsatını bulursa sağlamak isteyeceği oldukça sağlam ve de güçlü bir meşruluk kaynağı oluşturulur. Bu meşruluk tarzı öyle anlaşılıyor ki, günümüzde dahi, ulaşılmak istenen bir idealdir. Ancak pratik açıdan işlemesi oldukça zordur.

$\mathrm{Bu}$ formülasyon yöneticinin şahsında Tanrı ve kralı birleştirir. Böylece itaat sadece krallığın siyasal bir zorunluluğu ile değil tanrısallığın dinsel zorunluluğu ile de sağlanır. Ancak bu formülü sürdürmek sürekli ölümle pençeleşen Tanr1-kralların tanrısal boyutunu ayakta tutmak pek de kolay olmayacaktır. Bu anlayışta zamanla bir değişiklik oldu ve kralın Tanrı olamayacağı ancak O'nun soyundan gelebileceği düşüncesi yerleşti ki bunun en güzel örneği Çin imparatorlarıdır (Kapani, 1998: 68-69). Eski Yunan Kahramanlık Çağı düşüncesinde de Tanrının soyundan olmak doğrudan soylulukla ilişkilendirilir ve bu ilişki ile yönetme hakkı arasında bağlantılar kurulurdu. Homeros destanları bu siyasal düşünceye kaynaklık edecek birçok anlatı barındırır. Örneğin, yönetici Agamemnon'un soyu Zeus'a dayandırılır. Diğer yöneticiler de diğer tanrılarla ilişkilendirilir. Tanrıdan alınan bu yönetme hakkı anlayışı doğuştan gelen bir siyasal erdem anlamını taşımaktadır. Homeros'un anlatımında bu durumun sembolik anlatımı da oldukça anlamlıdır. Zira yönetme hakkını temsil eden asa, Zeus tarafından Atreus'a verilir, o da oğluna verir. Böylece asa ile sembolize edilen yönetme hakkı, babadan oğula geçecek bir sistemin meşrulaştırıcı aracı olur (Şenel, 2005: 112). Böylece kralların neden yönetici olduklarını açıklamaları kolaylaşacak, yönetme hakkının onlarda olduğu daha güçlü bir biçimde savunulabilecek ve kabul ettirilebilecektir.

Sayılan bu durumların yanı sıra günümüze yakın, özellikle H1ristiyanlık teolojisinin içinden üretilen etkili teokratik meşruluk modelleri de vardır. Bu dönem özelikle Ortaçağ sonları ile Yeniçağ başlarına rastlar. Dönemin önemli özelliği mutlak monarşilerin güç 
kazanmasıdır. Kralın tanrısal özelliği kalmamıştır ancak iktidarının kaynağı ilahidir (Kapani, 1998: 69).

Bazılarına göre her ne kadar, hayata dair hemen her şeyin dinsel olarak düzenlenmesinden dolayı, tarihin kaydettiği en dindar toplum Eski Yunan olsa da (Kılıçbay, 1994: 19) bu toplumun zamanla din ve mabet işlerini zenginleşme ile birlikte ikinci plana ittiği görülmüştür. Ancak bu durum laik bir yönetim için yeterli olmamıştır. Aynı şekilde Roma devrinde de dinin belirleyiciliği söz konusu olduğundan din dışı bir yönetime kaynaklık edecek tartışmalar daha az anlamlıdır. Laik bir devletin düşünülmesinde asıl anlamlı tartışmalar ve bu tartışmalara en önemli katkılar Hıristiyanlıkla birlikte sağlanmıştır. Çünkü Sezar'ın hakkını Sezar'a Tanrı'nın hakkını Tanrı'ya verin diyen bu anlayış cismani iktidarla ruhani iktidarı birbirinden ayırıyordu (Daver, 1993: 7-8). Bu ayrım, kilisenin dünyevi alana karışmayacağı gibi bir anlayışın yansıması olarak görülebilir. Ancak bu ilk argüman düşünülenin tersi bir sonuca yol açtı. Bu sonuç; kilisenin güç dengeleri arasındaki konumuna göre değişti ve kilise kendini güçlü hissettiği dönemlerde Sezar'ın hakkından hiç söz etmedi ya da Sezar'ın hakkının ancak Tanrı'nın istediği biçimiyle verilebileceğini savundu. Ancak iki dünya ayırımına Hıristiyanlığın yaptığı bu vurgu dünyevi alan-ruhani alan ayırımını da beraberinde getirdi. Laiklik tartışmalarında sıkça değinilen din ve devlet işlerinin ayrılması düşüncesi de buradan temel bulmaya başladı. Modern dönemlerde kilise aleyhine gelişen seküler düşüncelerin de bu ayrıma gönderme yaparak kilisenin eski alanına (din/öte dünya işleri) çekilmesi talep edildi.

Hıristiyanlık, hem Batı Roma ve hem de Doğu Roma'da devlet dini haline geldiğinde, kilise ruhani iktidarın tek sahibi idi. Ancak Batı Roma' da işler biraz daha farklı yürüdü ve zaman zaman laikler ile kilise arasında farklı dengeler kuruldu. Bu denge mücadelesinde laikler sıklıkla din alanının farklı olduğunu öne çıkardılar. Ama kilise de elinden geldiğince iki alanı kontrol etmeye çalıştı ve tıpkı Roma gibi tüm Avrupa'da örgütlenip etkisini arttırd1. Kilise dindevlet ayrımı yerine her alana müdahale etme isteği ile hareket edebildi. Yeni argüman, 'yeryüzü eğer Tanrı İmparatorluğunun bir parçası ise kilise de dünyevileşmeliydi' biçiminde somutlaştı. Böylece ekonomiye bulaştı, siyaseti ve adaleti yönetmeye başladı. Öyle 
oldu ki kararları kilise verdi, devlet uyguladı. Üstelik Roma yıkıld1ğında, kilise ayakta kalmıştı ve çok büyük imtiyazlar elde etmişti (Sezen, 1993: 17-18).

Kilise, güçlü ruhani etki ile güçlü cismani etkiyi birleştirdi. Bunun için Avrupa'nın parçalanmışlığını kullandı. Zira Avrupa'nın parçalanmışlığı ile birlikte güçlenen derebeyleri karşısında acze düşen krallar, Papa'dan yardım istediler. Bu arada ezilen halk öbür dünya saadeti vaat eden kiliseye güçlü bağlarla bağlandı. Bu iki gelişme kilisenin dünyevi iktidara hâkim olmasını pekiştirdi. Asıl vurgu ruhani iktidarın laik iktidara karşı üstünlüğü idi. Bu argüman özellikle kilise güçlü iken savunuldu. Ancak kilisenin zayıfladığı dönemlerde de dünyevi iktidara karşı bağımsızlık vurgusu yapılarak din alanının güçlü kalması sağlandı (Daver, 1993: 9-11). Hıristiyanlık ve dünyevi otorite ilişkisinin bu anlatımı oldukça ilginçtir. Zira özellikle iktidarın kim tarafından nasıl kullanıldığı, aynı referanslar alınsa bile günün şartları ve güç dengeleri tarafından nasıl belirlendiğini göstermektedir.

Söz konusu İslam olduğunda işin rengi biraz değişmektedir. İslam ortaya çıktığından kısa bir süre sonra siyasi bir form da taşıdı. Üstelik siyasal lider de peygamberdi. Bu dönemde din ve devlet işleri gibi bir ayrım insanların zihninde yer bulmuyordu. Dolayısıyla dinin dışında pür dünyevi bir alan algısı, ilgilenilmeyi hak edecek bir konu değildi. Hz. Muhammed'in vefatından sonra Allah'tan vahiy alan bir otoritenin olmaması bazı sorunlara neden oldu. Ancak bu da din dışı bir alandan ziyade "yönetici kim olmalı" sorusu ile ilişkiliydi. Meşru yönetim tartışmaları da yapıldı ve dinsel gerekçeler bulunarak otorite kullanılmaya çalışıld $1^{20}$.

Batı ile karşılaşma, batılı tartışmalara da dâhil olmak anlamına geliyordu. Batının tartıştığı din alanı ve din dışı alan ayrımı özellikle modernleşme sürecinde gündeme geldi. Yanı sıra yeni dünyevi ihtiyaçlar farklı formülleri de tartışılır kıldı. Özellikle İslami kavramlara batılı anlamlar yüklendi ve din çoğu zaman bir muhalefet aracı olarak kullanıldı. Günümüze yakın dönemlerde ise

20 Peygamber sonrası Müslüman toplumunun baş etmek zorunda kaldığı ilk büyük sorun olan yönetici seçimi ve politik teolojik sonuçlarının bir analizi için bkz. (Evkuran, 2006; Evkuran, 2016). 
yine batının etkisi ile İslamcılık, post-islamcılık, Euro-islam, fundamentalizm gibi konular tartışmaların seyrini belirlemektedir. Ancak profanlık konusunda İslam ülkelerinde de Batı ile benzer sorunlar/süreçler yaşandığından genel bir anlatım bu makale kapsamında yeteceğinden İslam ile ilgili bir başlık açmaya gerek duyulmamıştır.

\section{Profan Meşruluk Arayışları}

Tarihte teokratik devletten laik devlete geçiş süreci yönetimin aristokrasiden burjuvaziye geçiş sürecini de anlatır. Aristokrasinin meşruluğunu Tanrı'dan alması ve bu konuda yüzyıllardır süregelen bir geleneğin bulunması gücüne güç katıyordu. Ticaretin gelişmesi ile birlikte zenginliklerin yeni sinıfın elinde birikmesi yönetimin de el değiştirmesini zorunlu kılıyordu. Bunun için öncelikle yapılması gereken aristokrasinin elindeki meşruluk kaynağını çökertmekti. Aristokratlar dinsel kurumlarla kendilerini tanımlıyorlardı. Ancak bu kurumların çöktüğü yozlaştığı da bir gerçekti.

Fransız İhtilali sonrasında yaşananlar, yukarıda anlatıldığı gibi, kilise düşmanlığı hatta Hıristiyanlık düşmanlığının çarpıcı bir örneğidir. Ancak hem devrim öncesinde hem de devrim sonrasında bu karşıtlığın çok aşırıya gittiği başka yerler de görülecektir. Örneğin bir dönem Kuzey İtalya' da ki Padua'da kanunlara göre bir rahibin öldürülmesi hafif para cezası ile cezalandırılırken bir laikin öldürülmesinin cezası idam (Daver, 1993: 13) olarak belirlenmişti.

$\mathrm{Bu}$ arada farklı devletlerin dinin gücünü kullanma yarışı ve Protestanlık hareketinin yükselişi de papalığın zayıflaması ile sonuçlanmıştır. Sonuçta milli kiliselerin ortaya çıkması ve kiliselerin milli devletlere bağlanması süreci de yaşanmıştır. Fransa, Papalığa Fransız asıllıların getirtilmesi için uğraşmış buna karşın İngiltere'de de papalıktan ayrılan Anglikan Kilisesi kurulmuştur. Böylece İngiltere'de artık kral, kilisenin başı oluyordu (Sezen, 1993: 20-21).

Burjuna ekonomik kaynakları elinde bulunduruyordu ancak tüm yönetimlere hâkim olduğu söylenemezdi. Geleneksel bir meşruluktan yoksun olan yeni sınıfın meşruiyetini nereden alacağ 1 önem kazanmaya başladı. Tam bu arada milli egemenlik meşruluk krizinin çözümü için yetişti. 
Milli egemenlik kaynağını Rousseau'nun "Toplum Sözleşmesi" fikrinden alır. Bu anlayış meşruluk kaynağının tanrısal olmasına karşı çıkar ve dünyevilikte arar. Dayanak noktası "genel iradedir". "Genel irade, kişisel iradelerin sadece bir toplamından ibaret değildir: onlardan ayrı, onların üstünde kendine özgü varlığı olan kollektif bir iradedir." Bu irade hiçbir zaman yanılmayacak sürekli toplumun yararı için olacaktır (Kapani, 1998: 70-73). Millet'in de tanrı kadar soyut bir kavram olduğu düşünülürse teokratik meşruluk anlayışından ne kadar uzaklaşıldığı tartışma konusu olur. Zira sadece dayanak noktası olan referansın isminden başka değişen hiçbir şey olmadığı düşünülebilir. Üstelik milletin iradesinin somutlaşması esnasında da bir sürü sorun ortaya çıkacaktır. Dolayısıyla "milli irade" ile "seçmen çoğunluğunun siyasal tercihi" arasında kapanması imkânsız bir mesafe söz konusudur. Bu ve benzeri sorunlar milli egemenlik teorisinin ciddi problemli olduğunu hatta iddianın aksine metafizik bir kavrama dönüştüğünü anlatmaktadır (Kapani, 1998: 75vd.). Tam da burada Carl Schmitt'in açılamaları da hatırlanmalıdır. Onun "modern devlet kuramının bütün önemli kavramları dünyevileştirilmiş ilahiyat kavramlarıdır" derken kastettiği de aslında bu düşüncelere paraleldir. Ona göre "her şeye kadir Tanrı her şeye kadir yasa koyucuya dönüşmüştür" (Schmitt, 2005: 41vd.). Tüm bu açıklamalardan sonra birisi "Tanrı egemenliğinin" ancak "milletin kararı" ile gerçekleştirilebileceğini söylemesi durumunda ${ }^{21}$, egemenliğin millette ya da Tanrı'da olması hiçbir şeyi değiştirmeyecek, söylenenler sadece retorik olarak kalacaktır.

Gerçekten de egemenliğin kaynağının millet olması egemenliğin kutsal/dinsel/ilahi olmaktan çıktı̆̆ anlamına gelemez. Bu milletin tanımı ile de anlaşılabilir. Millet adeta Tanrı gibi; "geçmişte yaşamış" ve "gelecekte yaşayacak" bir unsur olarak görülür. Somut olarak gösterilemez.22 Bu aşkın varlık adeta bu dünyadan çok öte dünya ile ilişkilidir.

Şimdi profan bir meşruluk arayışı olan laiklik kavramına geri dönelim ve profanlık vurgusu çok belirgin olan Niyazi Öktem'in yaptığı laiklik tanımına başvuralım.

${ }^{21}$ Ali Bulaç bu iddiayı dile getirir (1995: 138).

${ }^{22}$ Millet kavramının tanımı için bkz. (Eroğul, 1993: 5). 
Öktem'e göre laiklik; "rasyonalizmdir (usçuluk-akılcılık) ... Aklın rehber alınması; safsata, hurafe, bilim dışı açıklamaların, irdelenmemiş "nakillerin" atılması, akılcı davranış modelleridir. Devlet yönetiminde bu yöntem izlenirse onun adı laikliktir." (Öktem, 1994: 34) Görüldüğü gibi bu tanım tüm kutsallıkları yadsımakta adeta pür profan bir yol önermektedir. Peki bu istek "milli irade" gibi soyut bir kavramla gerçekleştirilebilir mi? Aslında birçok düşünür, bu tarz bir iradenin olamayacağını vurgular. Özellikle, kavramın bilimsel olmaktan uzak olduğu ve bir dogmaya dönüştüğünün altını çizerler (Kapani, 1998: 79). Görüldüğ ü gibi kaynağını Tanrı'dan ya da tanrısallıktan almamakla birlikte "milli egemenlik" anlayışı doğaüstü hatta eleştirenlerin değişi ile "dogma" olabilmektedir.

Her ne kadar seküler bir kavram olsa da kutsallıkla bezenen milli irade yine de önemli bir işlevi yerine getirmektedir. Çünkü yönetimler için yönetilenlerin rızası oldukça önemlidir. Bu rıza oldukça, alınan kararlara uyum şiddet/zor kullanılmadan sağlanabilecektir. Sonuçta meşruluğun sağlandığ yerde şiddetin olmayacağ1 yargısına varılabilir (Kapani 1998: 84-85). Meşruiyet eksikliği yönetimi mutlaka yıkmasa da ciddi yaralar almasına neden olur (Sartori, 1996: 204). Üstelik teorik olarak, çoğulcu toplumlarda (ki çoğulculuk tek bir kutsalın hâkim olmadığını gösterir) herkes aynı değerleri ve inançları paylaşmadığını göre meşruiyet üretimi ancak kişilerin rızasına dayanabilir. Zaten siyasal literatürde oldukça geniş bir yer kaplayan toplum sözleşmesi gibi birçok teori de bu durumu beslemektedir (Rosenfeld, 2008: 25-216).

Tüm bu gerçeklerden yola çıkan yöneticiler, istikrarın sağlanması için kutsalın gücüne başvurmakta hatta dinsel kurallar üretmektedirler. Çünkü geniş halk kitleleri nazarında meşruluklarını sağlamak bu kutsallar dolayımı ile çok daha kolay olmaktadır. Ancak çoğu zaman "din olanı" sanki "din değilmiş gibi gösterme" çabası oldukça belirgindir. Zira eğer yapılanlar din olarak kabul edilse, dinin otoritesi farklı olduğundan söz sahibi olacak olanların kendileri değil de, dinin temsilcileri olması beklenir. Gerçi bu yeni dinin kurucuları olarak kendilerinin ürettikleri bu alanda onların sözlerinin geçmesi gerekir. Ama bunun önünde çok önemli bir engel görünmektedir. O da seküler yöneticilerin kendilerinden önceki dinsel meşruiyette elleri zayıf olduğu için kutsalla ilişkilerini oldukça za- 
yıflatmalarıdır. Dolayısıyla yeni duruma "din" adı vermeleri anlamlı olmayacaktır. Bu adlandırma kendilerini tutarsızlığa düşürecektir. Onun için sekülerlik iddiasının 1srarla sürdürülmesi ve ısrarla din dışı olunduğu vurgusu önem arz etmektedir.

\section{Profanın Pratiği: Kutsaldan Arınamama}

Seküler yönetimlerle ilgili şu iki tespit yapılabilir. Yöneticiler; öncelikle kullandıkları dinin ilahi dinlerden olduğunu iddia edemezler zira ilahi dinlerin belli gelenekleri var ve yöneticiler genellikle bu geleneğin dışındadırlar. İkinci olarak da doğaüstülüğün ve kutsallığın oldukça açık olduğu bir durum söz konusudur. Bu durumda, din dışı olunduğu iddiası pek inandırıcı olmayacaktır. Ancak iktidarlar, başka çareleri kalmadığından bu tarz doğaüstülüklerin/kutsallıkların din olmadığı yolunda ısrarlarını sürdüreceklerdir. Modern Ulus devlet bağlamı ile bu durumun günümüzdeki hemen her yönetim için geçerli olduğu söylenebilir.

Meşruluğun ne olduğu veya ne olması gerektiği konusunda belirleyici olanlar ve diğerlerini ikna edenler genellikle hâkim olanlardır. Hâkim olan sınıf/aile/din/kral/etnisite, şartlar değişince ya yeni duruma adapte olmak zorunda ya da yeni hâkimlere yerlerini bırakmak durumundadır. Yeni hâkim unsur kendi meşruluk kaynağını oluşturacaktır ki yönetimi alma sürecinde muhtemelen bunu oluşturmuştur. Tanrı-kral anlayışında kralların tanrı olmadıkları anlaşılınca, tanrının oğlu olduklarına dair inançların yerleştiğini görüyoruz. Başka bir aşamada kralın tanrısallığının olmadığı anlaşılınca kral, iktidarını sürdürmek için, bu iktidarın, tanrı tarafından kendisine verildiğinin alt yapısını hazırla(t)mıştır. Nihayet burjuvazi ekonomiye hâkim olunca, zenginliklerini daha iyi korumak için devletin de kendi elinde olmasını arzuladı. Aristokrasi gücünü kaybettiğinden, (burjuvazi) bu amacına ulaşabildi. Ancak meşruluğunu sağlamak için farklı bir şeylere dayanmalıydı; bu da "millet" olacaktır.

Görüldüğü gibi meşruluğun kaynağı hep soyuttur. Soyut olması, herkes tarafından müdahale edilemeyeceği anlamına gelir. Böylece hâkim olanlar tarafından oldukça geniş bir yelpazede yorumlanabilir. Tanrı ya da millet olmasının pratik açıdan çok da önemi yoktur. Sonuçta "maslahat icabı" yapılması gereken işler yü- 
rütülecektir. "Tanrının iradesi ancak demokrasi ile gerçekleşir" deyip demokrasiyi hiç tavizsiz uygulamak mümkün olabileceği gibi, milletin iradesi deyip diktatörlükler de meşrulaştırılabilir.

Meşruluk kaynağının soyut olması ve herkesin ikna edilmesinin zorluğu, ister istemez yönetimi belli bir çoğunluğun desteğini aramaya götürecektir. Yani, yönetimin bazılarınca (yönetimin ayakta kalabileceği kadar) meşru görülmesi gerekecektir. İnsanın yeryüzünde görülmesi ile birlikte "kutsal"ın (insan) hayatında önemli bir işlev gördüğünü biliyoruz. Kutsala karşı alınan tavır, yöneticiler açısından yönetimin meşruluğu için, (daha az zahmetle daha çok verim elde edilebileceği düşüncesi ile) kullanılmaya oldukça elverişli olduğundan, "kutsal", bir meşrulaştırma aracı olarak kullanıla gelmiştir. Hatta laik olduğunu özellikle vurgulayan birçok yönetim bu kolaycıllğa başvurmaktan kendisini alıkoyamamıştır. O zaman dinin bu günkü siyasal işlevini anlamlandırmak için bir soru ile devam etmek gerekir.

Din, acaba eskiden mi daha büyük bir güce ve işleve sahipti yoksa günümüzde mi? Bu sorunun cevabı bazılarınca üzerinde düşünmeye gerek dahi duymadan çok nettir. Yukarıda da değinildiği gibi bu grup dinin işlevinin gittikçe azaldığını söyleyecektir. Ancak aykırı düşünceler de var. Yukarıda değinilen Carl Schmitt ve benzer fikirler bunun önemli yansımalarını vermektedir. Ayrıca çok daha çarpıcı bir biçimde Hayes (1995: 31 vd.), bununla ilgili ciddi deliller ve gözlem sonuçları da sunacaktır. Ona göre; sanayi devrimi ile hızlanan bir gelişmenin sonucunda, sayıları gittikçe artan batılı entellektüeller, Hıristiyan dini mirasını önemsemiyorlar ve halk da bundan etkileniyordu. Kitlelerin Hıristiyanlıktan uzaklaşmaları dinden uzaklaştıkları anlamına gelemezdi. Bu durum entellektüeller için de geçerlidir. Oluşan inanç boşluğu doldurulmalıydı. Entellektüeller, "yarı dini bir bağlılık gösterdikleri", "bilimcilik", "insancllı", "pozitivizm", "hürmasonluk" gibi inanışları ile bu boşluğu doldurmayı hedeflediler. "Şüphesiz ki, bu merciler kitlelerin perestişi için fazla soyut, fazla batıni kalıyordu." O zaman entellektüellerin sunduğu başka teklifler değerlendirilecekti ki bunların en cazipleri milliyetçilik ve komünizm olmuştur. Sonuçta; insanların hayatlarında gerileyen dinin kendisi değil Hıristiyanlıktı. Yeni kutsalların üzerine oturtulan yeni dinleri görmek o kadar da zor olmayacaktır. 
Marx, "sabit ve durağan olan her şey buharlaşıyor, kutsal olan her şey ayaklar altına alınıyor ve insanlar sonunda yaşam koşullarına ve karşılıklı ilişkilerine ayık kafayla bakmak zorunda kalıyor" diyordu. Bu görüşleri, ilişkilerin kapital tarafından belirlendiğinin ifadesiydi. Bu noktada oldukça haklı görünüyor ancak "dinsel ve siyasi yanılsamalarla gizlenmiş sömürünün yerine açık, utanmaz, doğrudan ve kaba" sömürünün geçtiğini söylerken (Bostanc1, 1999: 27) "açık" ve "doğrudan" nitelemelerini ters çevirdiğimizde "kapalı" ve "dolaylı" nitelemeleri ile karşılaşırız ki bunların sadece "dinsel sömürü" (Marx'ın kastettiği anlamı ile Kapitalizm öncesi yapılar) araçları olduğunu söylemek, referansını bilinen bir dinden almayan düşüncelerin (ilişkilerin-yapıların) kutsallıktan arınmış, açık, doğrudan oldukları gibi bir ön kabulle hareket etmemize neden olur ki bu bizi yanıltacaktır. Şunu da belirtmek gerekir ki Marx'ın düşünceleri de kutsallıktan arınmış değildi. Bostancı (1999: 28), burjuvanın ilga ettiği kutsallığın ( burjuvanın kutsallığı ilga ettiğine katılmıyoruz, bize göre sadece kutsalın referans kaynağı değişti) Marx tarafından “insani özgürlükler temelinde" tekrar kurulduğunu söyler. Bu durum tartışılabilir ancak çok açık olan bir şey var ki o da Marksizm'in etkisi ile kurulan yönetimler devirdikleri kutsalların yerine yenilerini getirmekte fazla gecikmemişlerdir.

“Karl Marks'ın döneminden ve bilhassa da 1917 Rus Devriminden beri, komünizmin ekonomik cazibesinin yanı sıra, aşikâr bir dini cazibesi vardır. Alenen materyalist ve ateist olmasına rağmen, bir dünyevi cenneti vaat eder. Ermişleri ve şehitleri vardır, hekimleri ve sapkınlar vardır. Hararetle propaganda yapar ve takipçilerinin özel ve değişmez sadakatlerini ister. Kremlin'de artık tuhaf bir merkezi otoriteye; mahiyetçe aynı anda hem siyasi, hem dini, hem emperyal ve hem papalıkvari bir otoriteye sahiptir. Rakip bir dine, bilhassa da Hıristiyanlığa hiç tahammülü yoktur ve dünyayı fethetmek için kendine güvenle ileriye bakmaktadır." (Hayes, 1995: 32)

Marksizm kutsalın kalmayacağı noktasında çok iddialıydı. Ancak, sonuçta gelinen nokta, hayat tarzının kutsalla içli dışlı olması olarak da okunabilir. Buna paralel bir biçimde kutsalı direkt yadsımayan, sözgelimi milliyetçi akımların etkisi ile oluşan, (ulus) devletlerde bu durumun çok daha belirgin olduğunu görebiliriz. 
Hıristiyanlığın, aydınlanma döneminden sonra, yüceltilmesi bırakılınca yerini yeni din'in yüceltilmesi aldı. Bu dönem laik ve ulus devletin "takdis" edilmesine şahit olunmuştur. İngiliz Bolingbroke'un hedefleri arasında bir İngiliz kilisesi kurmak vardı. Ancak bu kilise "batıl inanca ya da ilahiyata dair hiçbir şeyle uğraşmamalı"ydı; ulus devletin dışında olmamalıydı. Anayasaya bağlı olması gereken bu kilise mensupları, "kendilerini diğer insanlara karşı Tanri'nın elçileri taslayanlardan" çok daha fazla tanrının elçisi olmayı hak ediyorlardı. Bolingbroke'la benzer düşünceleri paylaşan Fransız Raynal da şunları söylüyordu: "Devlet din için değil, din devlet için yapılmıştır... Devlet herşeyin üstündedir. Dünyevi iktidarla ruhani iktidar arasında ayrım yapmak düpedüz saçmalıktır..." (Hayes 1995: 72). Rayal burada devletin kutsallığına vurgu yapmakla, dinin bir araç olarak kullanılabileceğini de söylemiş oluyor.

Modern dönemlerin siyasal ideali konusunda çok yol kat edilmesine neden olan Fransız ihtilali aklın ışığında yapıldı. Birçok bakımdan dine başkaldırı niteliği taşıyordu. Peki kendi getirdiği kurallar dinin ne kadar dışında yer alıyordu.

“Aklın; sürekli milli tapınmaya mazhar olamayacak denli
soyut, fazlasıyla ateistik, devrimci Fransada'daki cereyan
eden olaylardan fazlasıyla uzak olduğu ortaya çıktı. Buna
karşı çıkan Robespierre'nin etkisiyle, onun yerine, deistik
bir Yüce Varlık kültü koyuldu. Robespierre'nin düşme-
sinden ve Direktorya'nın kurulmasından sonra, bir çeşit
törensel "etik kültürü", "Theophilanthropy" unvanıla
resmi din haline getirildi..." (Hayes, 1995: 85)

Marksizm gibi, Fransız Devrimi ile somutlaşan burjuva devriminin de hedefi dinden uzaklaşmaktı. Ancak oda bunu başaramadı. Üstelik yeni bir din getirdi. Bu yeni din bildiğimiz anlamdaki dinlerden çok daha güçlü ve çok daha kapsayıcıydı. Bu dinin de tapındığı/ibadet ettiği tanrıları, kutsal simgeleri, kutsal mekânları vardı. Şimdi, Hayes'in (1995: 227-254) çalışmasına dayanarak yeni din ile eski din arasındaki benzerlikleri gösterdiğimizde konu daha iyi anlaşılmış olacaktır:

(i) Bu yeni dinin de bir ilahı var. Bu ilah, kişinin "milli devletinin hamisi ve ya tecessüm etmiş" halidir. Sam Amca (Amerikalı), Boğa John (İngiliz), Marianne (İskoç), Hans (Alman), İvan (Rus) ve bunun gibileri şakavari bir 
tarzda belirebiliyorlar. "Yine de seçilmiş bir halkın tanrısı, kıskanç bir tanrı, esasen savaş tanrısıdır o."

(ii) Milliyetçilik (yeni din), akıl ile "spekülatif bir milliyetçilik teolojisi ve mitolojisi", muhayyile ile ezeldenebede yaşayacak millet için "gaybi bir alem", duygularla (tapınılan tanrının rızasını kazanmayı sağlayacak) törensel ibadet alanlarını kurar.

(iii) Milli devlet üyelerini dış şeytanlara karşı koruduğu gibi, onları rızıklandırmaktadır da.

(iv) Her yeni doğan insanın laik devlet tarafından tescili, aslında kilisenin vaftiz törenleri gibidir. Sonra devlet onu "milli ilmihal dersleri" için okullarında eğitir. Kilise ve tabii ki ulus devlet sadece doğumlarla değil evlilik ve ölümlerle de kendisini gösterir. “Eğer milliyetçilik adına savaşmışsa, kabrine kulluğunun alameti koyulur... I. Dünya Savaşı'ndan beri milli başşehirdeki en kutsal türbe, "Meçhul Asker Kabri" dir. Sürekli çiçeklerle bezeli olan burada sürekli 1şıklar yanar."

(v) Yeni dinlere üye olmak zorunludur. Ya ölümle ya da göçle çıkabilirsiniz ancak ikinci yol sadece mezhep değiştirmekten ibarettir. Çünkü şu anda pratikte hiçbir ülkenin hâkim olmadığı bir toprak parçası yok gibidir.

(vi) "Modern milliyetçilik ayini, diğer bazı dinlerden daha basittir; ama nispeten genç olduğu gözönüne alınırsa, bu ayin oldukça iyi geliştirilmiştir. Bu ayinin başta gelen sembolü ve merkezi tapınma nesnesi, milli bayraktır"23 Milli bayraklarla ilgili bir tören yapıldığında onunla birlikte vazgeçilmeyen bir şey de "milli marş"tır. ${ }^{24}$

\footnotetext{
23 "Dar anlamda konuşursak, Avrupa kıtasında hiçbir şey 18. yüzyılın sonlarındaki Fransız devriminden önce gelmez; Birleşik Devletler'in yıldızları ve şeritleri de daha eski değildir... Bayrağı "selamlama"nın, "yarıya indirme"nin, "indirme"nin, "göndere çekme" nin evrensel ayin biçimleri vardır. Erkekler yanlarından bayrak geçtiğinde şapkalarını çıkarırlar; şairler bayrağa hamd ve sena etmek için kasideler yazarlar ve çocuklar bayrak için ilahiler okur, sadakat yeminleri ederler." (Hayes, 1995: 231).

${ }^{24}$ Milli marş edebi açıdan hiç kayda değer olmayabilir. Ancak bu profan bir metinmiş gibi eleştirilemez. “Te
} 
(vii) Hıristiyanlıkta olduğu gibi Milli devletlerin de kutsal günleri ${ }^{25}$ vardır.

(viii) Milli devletlerin de tapınaklar1 ${ }^{26}$ vardır.

Hayes'in saydıklarından başka şunları da ekleyebiliriz.

(ix) Milliyetçiliğin kutsallığını pekiştiren bir yönü de seçilmişlik mitidir. Bu mit, “...modern öncesi, kutsal etnik seçilmişlik mitinin laik, modern muadilidir." (Smith, 1994: 136) (Her din mensubunun, tanrının gerçek dinini kendisinin mensup olduğu din olarak görmesinde olduğu gibi.)

(x) Her milletin dili de kutsal idi. Bu kutsal dil (resmi dil) ile yeni dinin tüm gerekleri (ibadetleri) yerine getirilecekti. ${ }^{27}$

(xi) Her millet "biz ve onlar" tanımlaması yapar. Bu asıl belirleyicidir. Millet başkası olmamakla anlam kazanır. Millet; "bizdir", “onlar" değildir (Türköne, 1994: 54). Yani müminler ve kâfirler vardır.

Deum (Allah'a hamd ve övgü. Hıristiyan ayininde ilahinin açlış sözleri... yeni tertibi ile okunmaya başlandığında kullar ayağa kalkar, askerler "hazır ol"a geçer, erkek siviller şapkalarını çıkarırlar, harici saygı ve ihtiramın her türlüsü gösterilir." (Hayes, 1995: 231-232).

25 “Hırıstiyan Kilisesi nasıl Paganizm'den bazı bayram günlerini alarak benimsemişse, milli devlet de

Hıristiyanlık'tan birtakım bayram günleri almıştır. Mesela, Birleşik Devletler'de, Dört Temmuz milliyetçi bir Yılbaşı' dır, Bayrak Günü Corpus Christi (Hz. İsa'nın cismi)'nin bir uyarlaması, Nişan Günü ya da Gaziler Günü de Tüm Ruhlar Günü'nün vatansever bir versiyonudur. Hıristiyan takvimindeki azizlerin günlerini takliden, Washington ve Lincoln gibi milli azizlerin ve kahramanların doğum günleri kutlanır." (Hayes, 1995: 232).

26 "Amerikalıların en fazla kutsallaştırdığı yerleri ve yapıları görmek isteyen birisi, Hıristiyan katedrallerini değil, Philadelphia' daki Bağımsızlık binasını, Boston'daki Faneuil Binasını, Lexington'daki General Lee'nin ve New York'ta da General Grant'ın türbelerini; bütün bunlardan başka, kubbeleriyle ve sütunlarıyla, Kongre ve Yüksek Mahkeme tapınaklarıyla, Beyaz Saray'ıyla, Lincoln, Jeferson ve Washington abideleriyle, Arlington ve Vernon Tepesi yatırlariyla popüler haccın tam bir mekkesi olan, milli başşehri gezmek zorundadır." Hayes, 1995: 232. Bu örnekler dünyanın bütün ülkeleri için kısmen de olsa geçerlidirler.

${ }^{27}$ Eski kutsal diller (Latince, Yunanca, İbranice) yeni yayıncılık anlayışı ile diğer dillerin seviyesine indi. Ve hiçbiri artık Tanrı'ya ait değilse her millet kendi dilini seçecekti (Anderson, 1995: 87-88.). Yani hepsi kendi dilini kutsal sayacak ve değişmez (resmi dil) kılacaktı. 
Yukarıda verdiğimiz örnekler bugün laik olduklarına inandığımız tüm devletler için geçerlidir. Oysaki buradan da anlaşılacağ 1 gibi bu uygulamalar hiç de din dışı değillerdir. Bunların din dışı olamamaları laik devletin milliyetçilikle olan göbek bağından kaynaklanmakta olduğunu söyleyebiliriz ki Hayes'in laik devletin "ilahlaştırılması" nın modern çağlardaki tek biçiminin milliyetçilik olduğunu söylerken kastettiği budur (Hayes, 1995: 251). Ancak bize göre milliyetçilik sadece bu gün açısından işlevsel bir değeri olduğundan kutsallaştırma aracı olarak kullanılıyor. Yarın başka ideolojik kutsallık araçları da ortaya çıkabilir. İktidarın sürmesi için yöneticilerin kutsala başvurmaları, işlerini kolaylaştıracağından bu konuda amaca giden her yolu meşru görme eğilimleri vardır. Yoksa eski çağlarda kralların ya da Marksizm'deki iş̧̧i sınıfının kutsal olmasından, temelde, milliyetçiliğin hiçbir farkı yoktur.

Son olarak şu soru akla gelebilir: bugün laik denilen uygulamalar kutsalı içeriyor olsa dahi bu uygulamaların işlevsel bir değeri var, bunlar toplumun huzuru için değişebilen ve dogmadan uzak kurallar olduğundan, dinsel kurallardan daha elverişli değiller midir? Kuralların değişebilir olması topluma ayak uydurulması açsindan önemlidir. Ancak bu sadece laik kurallar için değil tüm kurallar için geçerlidir. Örneğin 9. yüzyılda İslam uleması içtihat kapısının kapandığını söyleyerek (İnalcık, 1996: 319); gerek kamu hukukunda ve gerekse fertler arasındaki ilişkilerde tek bir kanun(şeriat)un uygulanacağını dile getiriyordu. Bu durum İslam fıkhında oldukça kabul gördü ve bunun dişına çıkılmaz oldu. Ancak değişen şartlar (sözgelimi Osmanlı Devleti'nde böyle oldu) şeriatı aşan bazı kurallar gerektirebiliyordu. Üstelik Osmanlı devleti örneğini ele alırsak; bu devlet, meşruluğunu şeriata dayandırıyor olmasına rağmen, şeriatın dışına çıkabiliyorsa, din kurallarının da zamanla değiştiğini anlayabiliriz (İnalcık, 1996: 318-341). Eğer laik kuralları sadece değişme özelliği ile ele alırsak din kurallarından sadece dayandırıldıkları kaynak noktasından ayırmış oluruz ki bu da gerçeği tam yansıtmaz. Zira Tanri'yı konuşturan (en azından Tanrı'nın ne demek istediğine karar veren) insanlar olduğundan, dine dayalı olduğu söylenen kurallarla laik kuralların içerikleri pek farklı olmayabilir.

En ilkel toplumlarda bile "kutsallık ile rasyonellik" bir arada bulunabiliyordu. Amazon yerlilerindeki bir kurala göre avcıya avı 
tabu kılınmıştı. Bu kural yaşamın sürmesi için toplumsal dayanışmanın bir gereği olarak oldukça önemli bir işlev görüyordu (Bostanc1, 1999: 86). Bu kuralın gördüğü işlev değerlendirildiğinde toplumun buna ihtiyacı varsa ister ilkel, ister gelişmiş bir toplum olsun bunu karara bağlaması gerekir. Ve bu karar verilirken içine kutsal tonların karıştırılması yönetimin işini kolaylaştıracağından, gelişmiş laik yönetimlerde de bu gibi kutsallıkla karışık rasyonel kurallara rastlamak şaşırtıcı olmayacaktır.

Önceleri kutsal tonlarda rasyonel kurallar vardı, şimdi ise rasyonel tonlarda kutsal kurallar var. Dolayısiyla, bizce toplumun ihtiyacı ya da, daha yerinde bir değişle, iktidarın ihtiyacı doğrultusunda gerçekleşen kuralların geçmişte neye göre yapılıyorsa şu anda da ona göre yapıldığını söylemek çok da yanlış olmazsa gerek. Yani geçmişin kuralları ile şimdinin kuralları (değerlendirdiğimiz anlamda) renk değişikliklerinden ibarettir.

\section{Sonuç}

Dinin ne işe yaradığ1 sorusuna verilen cevap ile dinin ne olduğu arasında bir bağ kurulduğunda; dünyevi olduğundan şüphe duymayacağımız ve belli ideolojiler ve kimliklerle hayat bulan devletin; insan hayatını yöneten/yönlendiren, onlara dünyayı anlama ve yorumlama perspektifi sunan yönü ile ne kadar dinsel fonksiyonlar yerine getirdiği anlaşılmaktadır. Üstelik dinin ibadet ve törensel yönlerini de devlet pratiğinde bulmak mümkündür. Bu devlet eğer teokrasi olma iddiasındaysa en azından teorik düzeyde dünyevi bir yönetimi dinsel bir bağlama oturtmuş olacak ve belli bir tutarlılık taşıyacaktır. Tanrı krallar, yarı tanrısal krallar, tanrıların soyundan gelen krallar veya peygamberler gibi yöneticiler bu tutarlılığı taşırlar. Çünkü yönetimlerinin meşruluğu onların Tanrı ile ilişkilerinden yani din olma ya da dini temsil etme iddialarından kaynaklanmaktadır. Ancak özellikle Aydınlanma sonrası modern dönemlerde profanlık iddiası taşıyan yönetimler ve/veya yönetim teorileri din olma ya da dini temsil etme iddiası taşımamalarına rağmen, dinsel bazı fonksiyonlar barındırmaya devam ettiklerinden tutarsızlık ortaya çıkmaktadır.

Bu tutarsızlık; profanlık iddiası taşıyan yönetimlerin, din dışı olmaya yaptığı vurguya rağmen yeni kutsallıklar ürettiği ve bu kutsallıkların da dinsel bir pratiğe dönüştüğünü anlatmaktadır. Peki, 
sorun aşılamaz mı? Aslında teorik düzeyde her ne kadar dinden arınmış bazı düşünceler ve bu düşüncelerin yansıdığı toplumsal bazı kurumlar (ki buna devlet de dâhildir) söz konusu olsa da şu ana kadar görülen pratiklerin bu idealin çok dişında olduğu görülür.

Dinsellik yöneticilerin elini güçlendirir, güçlerine güç katar ve daha kolay yönetmelerini sağlar. Bundan dolayıdır ki komünizm gibi dinden arınmayı önceleyen modern devlet uygulamaları da dâhil olmak üzere, oldukça farklı sınıflandırmalara tabi tutulabilseler de, dinsellikten arınmış bir devlet yapısı, daha doğrusu (iddia başka türlü olsa da) dinsellikten arınmak isteyen bir devlet yapısı bulunmamaktadır. Devletler adına ya da bu devletlerin idealleri adına üretilen kutsallıklar bir dinin ürettiklerinden çok da farklı değildir. Ancak daha çarpıcı ve daha somut olanı; ritüeller, seremoniler, marşlar, üniformalar, bayramlar, kutsal günler, kutsal kişiler, yasalar, semboller, okullar gibi profan bir sistem adına üretilen ve neredeyse gündelik yaşamın her alanına sızan pratiklerin de dinsel karşılıklarına oldukça benzer olmalarıdır.

Siyaset biliminin verileri devletin varlı̆̆ 1 ile birlikte kurumsal olarak, bazı insanların avantajlı bazılarının ise dezavantajlı olmaya başladığını söyler. Sosyoloji ise toplumun içinde farklılıkların olduğunu ve değişimle birlikte bu farklılıkların çeşitlenebildiğini anlatır. Avantaj ve dezavantaj dengesinin korunması ve farklılıkların yönetilebilmesi için her yönetimin meşru bir iktidar kullanması gerekir. $\mathrm{Bu}$ meşruiyet kutsallık barındırmadan bu eşitsiz durumu sürdürmeye yardımcı olamaz. Çünkü devletler barındırdıkları tüm farklılıklara karşı yansız olamazlar, zaten yansız olurlarsa bu durum devletin varlık nedenine ters olur. Dünyevi olan devletin varlık nedenini ancak onu aşan ve gücü karşısında tüm farklılıkları eşit yapabilecek bir güç sonlandırabilir.

Avantajlıları sayı doğrusunda bir değer vererek anlatırsak; soyluların, zenginlerin, güçlülerin, güzellerin/yakışıklıların vb. sıradan insanlara göre daha büyük sayısal değerleri olacaktır. Ancak bunların yüksek değerleri ile sıradan insanların küçük sayısal değerleri sonsuz karşısında ayni şeyi ifade ederler. İşte yanında eşit olunacak bu muazzam güç ancak Tanrı olabilir. Onun için devletler 
dini de kontrol etmek isterler ancak bu yetmeyeceğinden yeni dinsel alanlar da oluştururlar. Dolayısıyla profan meşruluk ulaşılması güç bir hayal gibi durmaktadır.

\section{Kaynakça}

Anderson, Benedict. (1995). Hayali Cemaatler, Çev. İskender Savaşır, İstanbul: Metis Yayınları.

Aron, Raymond. (2006). Sosyolojik Düşüncenin Evreleri, Çev. Korkmaz Alemdar, İstanbul: Kırmızı Yayınları.

Barry, Norman P. (2004). Modern Siyaset Teorisi, Çev. Mustafa Erdoğan ve Yusuf Şahin, Ankara: Liberte Yayınları.

Bostancı, Naci. (1999). Bir Kolektif Bilinç Olarak Milliyetçilik, İstanbul: Doğan Yayınevi.

Bulaç, Ali. (1995). Modern Ulus Devlet, İstanbul: İz Yayıncılık.

Daver, Bülent. (1993). Siyaset Bilimine Giriş, Ankara: Siyasal Yayınları.

Duman, Fatih. (2010a). Aydınlanma Eleştirisinden Devrim Karşıtlı̆̆ına: Edmund Burke, Ankara: Liberte Yayınları.

Duman, Fatih. (2010b). “Toplumsal Hafıza, (Fransız) Devrim(i) ve Sosyal/Siyasal Kuram", Muhafazakâr Düşünce, Y. 6, S, 24, ss.13-40.

Duman, Fatih. (2010c). “Ulus-Devlet: Rousseaucu Genel İrade Bağlamında Bir Değerlendirme", Demokrasi Platformu, Y. 6, S. 23, ss. 89-116.

Durkheim, Emile. (2005). Dini Hayatın Ilkel Biçimleri, Çev. Fuat Aydın, İstanbul: Ataç Yayınları

Eroğul, Cem. (1993). Anatüzeye Giriş, Ankara: İmaj Yayınları.

Mehmet, Evkuran. (2006). "Peygamber, Karizma ve Siyasal Otorite", İslami İlimler Dergisi, Y.1, S.1, ss.51-67.

Evkuran, Mehmet. (2016). Sünnî Paradigmayı Anlamak- Bir Ekolün Politik ve Teolojik Yapılanması, Ankara: Ankara Okulu Yayınları.

Gauchet, Marcel. (2000). “Anlam Borcu ve Devletin Kökenleri: İlkellerde Din ve Siyaset", Çev. Ozan Erözden, Devlet Kuramı, Der. Cemal Bali Akal, Ankara: Dost Kitabevi, ss. 33-67.

Giddens, Anthony. (2006). "Pozitivizm ve Eleştiriciler", Çev. Levent Köker, Sosyolojik Ç̈̈zümlemenin Tarihi, Der. Tom Bottomore ve Robert Nisbet, İstanbul: Kırmızı Yayınları, ss.345-412.

Hamilton, Malcolm. (2001). The Sociology of Religion: Theoretical and Comparative Perspectives, Londra, New York: Routledge

Hançerlioğlu, Orhan. (1999). Felsefe Sözlüğü, İstanbul: Remzi Kitabevi.

Hayes, Carlton J. H. (1995). Milliyetçilik Bir Din, Çev. Murat Çiftkaya, İstanbul: İz Yayınları. 
Heywood, Andrew. (2012). Siyasetin Temel Kavramları, Çev. Hayrettin Özler, Ankara Adres Yayınları.

Horton, Robin. (1960). "A Definition of Religion, and its Uses", The Journal of the Royal Anthropological Institute of Great Britain and Ireland, Vol. 90, No. 2, pp. 201-226.

İnalcık, Halil. (1996). Osmanlı İmparatorluğu Toplum ve Ekonomi, İstanbul: Eren Yayınları.

Kapani, Münci. (1998). Politika Bilimine Giriş, Ankara: Bilgi Yayınevi.

Kılıç, Ahmet Faruk. (2007). "Fransız Devrimi ve Din”, Muhafazakâr Düşünce, Y. 3, S. 11, ss. 119-142.

Kılıçbay, Mehmet Ali. (1994). "Laiklik ya da Bu Dünyayı Yaşamak", Cogito, S.1, ss.15-22.

Kırbaşoğlu, Hayri M., (2010). Ahir Zaman İmihali, Ankara: OTTO Yayınları.

Kurt, Abdurrahman. (2008). "Sosyolojik Din Tanımları ve Dine Teolojik Bakış Sorunu", Uludă̆ Üniversitesi Illahiyat Fakültesi Dergisi, C.17, S.2, s. 73-93.

Lipson, Leslie. (2005). Siyasetin Temel Sorunları, Çev. Fügen Yavuz, İstanbul: İş Bankası Yayınları.

Marx, Karl. (2000). Hegel'in Hukuk Felsefesinin Eleştirisi, Çev. Kenan Somer, Ankara: Sol Yayınları.

Nisbet, Robert. (2013). Sosyolojik Düşünce Geleneğgi, Çev. Yusuf Kaplan, İstanbul: Paradigma Yayınları.

Orhan, Özgüç. (2013). “Jean-Jacques Rousseau'da Sivil Din Kavramı”, Ankara Üniversitesi SBF Dergisi, C. 68, No. 3, ss. 1-35.

Otto, Rudolf (2014). Kutsala Dair, Çev. Sevil Ghaffari ,İstanbul: Altıkırkbeş Yayınları.

Öktem, Niyazi. (1994). "Dinler ve Laiklik", Cogito, S. 1, ss. 33-50.

Örnekleri ile Türkçe Sözlük. (1995). Ankara: Milli Eğitim Bakanlığı Yayınlar.

Rosenfeld, Michel, (2008). “Hukuk Devleti ve Anayasal Demokrasinin Meşruiyeti", Çev. Ali Rıza Çoban, Hukuk Devleti: Hukuki Bir İke Siyasi Bir İdeal, Der. Ali Rıza Çoban, Bilal Canatan ve Adnan Küçük, Ankara: Adres Yayınları, ss. 211-255.

Rousseau, Jean-Jacques. 2006. Toplum Sözleşmesi, Çev. Vedat Günyol, İstanbul: İş Bankası Yayınları.

Sartori, Giovanni. (1996). Demokrasi Teorisine Geri Dönüş, Çev. Tunçer Karamustafaoğlu ve Mehmet Turhan, Ankara: Yetkin Yayınları.

Schmitt, Carl. (2005). Siyasi İlahiyat: Egemenlik Kuramı Üzerine Dört Bölüm, Çev. A. Emre Zeybekoğlu, Ankara: Dost Kitabevi Yayınları.

Sezen, Yümni. (1993). Türk Toplumunun Laiklik Anlayışı, İstanbul: Marmara Üniversitesi İlahiyat Fakültesi Vakfı Yayınları. 
Metin Uçar

Smith, Anthony D. (1994). Milli Kimlik, Çev. Bahadır Sina Şener, İstanbul: İletişim Yayınları.

Şenel, Alaaddin. (2005). Siyasal Düşünceler Tarihi, Ankara: Bilim ve Sanat Yayınlar1.

Tocqueville, Alexis de. (1995). Eski Rejim ve Devrim, Çev. Turhan Ilgaz, İstanbul, Kesit Yayıncılık.

Turner, Bryan S. (1998). "Sivil Din”, Çev. Yasin Aktay, Din Sosyolojisi, Der. Yasin Aktay ve M. Emin Köktaş, Ankara: Vadi Yayınlar, ss. 238-251.

Türköne, Mümtaz'er. (1994). Modernleşme, Laiklik ve Demokrasi, Ankara: Ark Yayınları.

Vrijhof, P. Hendrik. 1998. “Din sosyolojisi Nedir?”, Çev. M. Emin Köktaş, Din Sosyolojisi, Der. Yasin Aktay ve M. Emin Köktaş, Ankara: Vadi Yayınlar, ss. 275-298.

Yeğin, Abdullah. (1991). Osmanlıca-Türkçe İslami-İlmi-Edebi-Felsefi Yeni Lugat, İstanbul: Hizmet Vakfı Yayınları. 